\title{
Nutrients, Genetic Factors, and Their Interaction in Non-Alcoholic Fatty Liver Disease and Cardiovascular Disease
}

\author{
Rosa Lombardi ${ }^{1,2} \oplus$, Federica Iuculano ${ }^{1}$, Giada Pallini ${ }^{1}$, Silvia Fargion ${ }^{1}$ and \\ Anna Ludovica Fracanzani 1,2,* \\ 1 Department of Pathophysiology and Transplantation, University of Milan, 20122 Milan, Italy; \\ rosa.lombardi@unimi.it (R.L.); federica.iuculano@unimi.it (F.I.); \\ giada.pallini@unimi.it (G.P.); silvia.fargion@unimi.it (S.F.) \\ 2 Ca' Granda IRCCS Foundation, Policlinico Hospital of Milan, 20122 Milan, Italy \\ * Correspondence: anna.fracanzani@unimi.it
}

Received: 30 October 2020; Accepted: 16 November 2020; Published: 19 November 2020

\begin{abstract}
Non-alcoholic fatty liver disease (NAFLD) is the most common chronic liver disease in Western countries and expose patients to increased risk of hepatic and cardiovascular (CV) morbidity and mortality. Both environmental factors and genetic predisposition contribute to the risk. An inappropriate diet, rich in refined carbohydrates, especially fructose, and saturated fats, and poor in fibers, polyunsaturated fats, and vitamins is one of the main key factors, as well as the polymorphism of patatin-like phospholipase domain containing 3 (PNPLA3 gene) for NAFLD and the apolipoproteins and the peroxisome proliferator-activated receptor (PPAR) family for the cardiovascular damage. Beyond genetic influence, also epigenetics modifications are responsible for various clinical manifestations of both hepatic and CV disease. Interestingly, data are accumulating on the interplay between diet and genetic and epigenetic modifications, modulating pathogenetic pathways in NAFLD and CV disease. We report the main evidence from literature on the influence of both macro and micronutrients in NAFLD and CV damage and the role of genetics either alone or combined with diet in increasing the risk of developing both diseases. Understanding the interaction between metabolic alterations, genetics and diet are essential to treat the diseases and tailoring nutritional therapy to control NAFLD and CV risk.
\end{abstract}

Keywords: nutrigenomic; fructose; PUFA; micronutrients; cardiovascular disease; NAFLD; diet; epigenetic; PNPLA3; genetic influence

\section{Introduction}

Non-alcoholic fatty liver disease is defined by the presence of fat in more than $5 \%$ of hepatocytes without excessive alcohol consumption and after exclusion of all other causes of liver disease. It is the most common chronic liver disease in Western countries [1] and includes a group of hepatic disorders ranging from simple steatosis to more progressive forms such as non-alcoholic steatohepatitis (NASH), characterized by hepatic inflammation, and hepatic fibrosis, possibly leading to NAFLD-related cirrhosis and hepatocellular carcinoma.

NAFLD is characterized by metabolic alterations, mostly overweight and central obesity, dyslipidemia, hypertension, insulin-resistance, and type 2 diabetes mellitus so that the acronym NAFLD has been substituted with the term MAFLD (i.e., metabolic associated fatty liver disease) [2]. However, given the really recent coin of MAFLD term and the almost totality of literature data on fatty liver disease referred as NAFLD, in the present review, we'll keep using the acronym NAFLD. 
This metabolic imbalance exposes NAFLD patients to increased cardiovascular (CV) risk, so that the leading cause of mortality in patients with NAFLD is cardiovascular disease (CVD) [3]. Besides coronary artery disease, patients with NAFLD present also higher rate of atrial fibrillation, heart failure, atherosclerosis, altered arterial stiffness, and myocardial remodeling [4].

Actually, NAFLD and CVD share common pathogenetic risk factors. Insulin resistance is one of the key factors in the development of both diseases, prompting increased circulation of free fatty acids (FFAs) to the liver and imbalance in lipid metabolism, with consequent hepatic and vessels fat accumulation [5]. Increased lipid accumulation fosters mitochondrial dysfunction by lipo-toxicity and activation of oxidative stress, both in the liver and in peripheral arteries. Moreover, impairment in lipid metabolism enhances hepatic production of adipokines and inflammatory cytokines, as well as of procoagulant factors. In addition, diet may alter gut microbiota, which is involved in bile acid metabolism and systemic and hepatic inflammation [1].

Both environmental factors and genetic predisposition play a central role in sustaining the above-mentioned pathogenetic mechanisms. Among environmental factors, an inappropriate diet, rich in refined carbohydrates, especially fructose, and saturated fats, and physical inactivity are the key factors. As for the genetic substratum, the polymorphism of I148M PNPLA3 gene (patatin-like phospholipase domain containing 3) is the major determinant of NAFLD, whilst the transmembrane 6 superfamily member 2 gene (TM6SF2), the membrane bound O-acyltransferase domain-containing 7 gene (MBOAT7), and the glucokinase regulatory protein (GCKR) variants play a minor role [6]. Conversely, TM6SF2 mutation seems to reduce CV risk [7]. Along with genetic alterations, epigenetics modifications are also responsible for various clinical manifestations of both hepatic and CVD.

Nowadays, no established pharmacological treatment is available for NAFLD, so that modification in lifestyle, especially diet and regular physical exercise, are standard of care. Similarly, the same approach is advisable to prevent and manage CVD. Many dietary approaches have been proposed and the Mediterranean diet has recently been shown to have a role in improving risk factors associated with metabolic syndrome and NAFLD [8], as well as in reducing CV events [9].

Given the complexity of NAFLD and cardiovascular disease, understanding the interaction between metabolic alterations, genetics, and diet, is essential to treat the diseases and tailoring nutritional therapy to control NAFLD and CV risk.

The aim of our review is to explore the impact of macro and micro-nutrients on development and progression of NAFLD and to assess their influence on CV risk, as well as the interplay between micro/macro-nutrients and genetic substrate in the etiopathogenetic pathway. Finally, we will also report our preliminary data of an observational study conducted at the Outpatient Hepatology Service of Policlinico Hospital of Milan evaluating the impact of macro and micronutrients on liver disease and cardiovascular damage in patients with NAFLD.

\section{Role of Carbohydrates in NAFLD and Cardiovascular Disease}

\subsection{Carbohydrates and NAFLD}

The Mediterranean diet is one of the mostly suggested dietetic regimen for patients with NAFLD and is characterized by reduced carbohydrate intake ( $40 \%$ of the calories vs. $50-60 \%$ in a typical low-fat diet), with particular decrease of sugars and refined carbohydrates [9].

Carbohydrates are classified into monosaccharides (fructose, glucose, and galactose) and disaccharides. Fructose is naturally present in fruits; however, it is often present in the form of added sugar, as a sweetener to other products such as soft drinks, biscuits, and bakery products in the form of sucrose (made of $50 \%$ of glucose and $50 \%$ of fructose) and high fructose corn syrup (HFCS) (with up to $55 \%$ of fructose).

Fructose has been demonstrated as the main carbohydrate determinant in hepatic fat accumulation. In fact, Schwarz et al. [10] demonstrated a higher fat accumulation in patients exposed to a high-fructose 
diet compared to those with a diet poor in fructose and rich in complex carbohydrates like cereals, bread, pasta, rice, and potatoes.

Indeed, fructose exerts a negative metabolic effect promoting de novo lipogenesis (DNL) and hepatic fat accumulation [11] either directly, being a substrate of DNL, or leading to a hyperproduction of Acetyl-Co-A from citrate, another substrate for DNL as well as a powerful activator of key enzymes in the DNL itself [12]. In addition, the higher intake of fructose fosters oxidative stress and hepatic insulin resistance [13], which, along with intrahepatic fat accumulation, promote the development of hepatic steatosis and cardiometabolic events [14,15]. Moreover, fructose inhibits the production of insulin and leptin, hormones which modulate the feeling of satiety, fostering increased energy intake and weight gain. Finally, fructose ingestion alters gut microbiota, with a reduced capacity to degrade carbohydrates to short-chain fatty acids, and increases gut permeability promoting metabolic dysfunction [16].

Population studies revealed a close association between overconsumption of added sugar (e.g., sucrose and high-fructose corn syrup) and the presence of NAFLD in both adults and children [17-19]. In particular, the Framingham Heart Study, involving more than 2600 subjects examined by abdomen computer tomography for the presence of NAFLD, showed a dose-response association between soft drinks consumption and fatty liver disease [20]. In addition, soft-drinks' usual consumers with NAFLD have a higher rate of inflammation and fibrosis [21] compared to non-consumers, and an improvement of liver histology consequent to fructose restriction has been demonstrated [22]. In contrast, Cortez-Pinto et al. [23] reported in a cohort of 45 biopsy proven NAFLD patients a higher consumption of fat and less carbohydrate in NASH subjects compared to non-NASH ones, with only a slight increase in the consumption of fructose in those with more severe histological features.

Besides observational data, a large number of interventional studies explored the role of carbohydrates in patients with NAFLD.

Solid data demonstrated that consumption of a high-fructose diet even for a short term (i.e., 1-2 weeks) significantly favor hepatic fat deposition [24-26], possibly because of the stimulation of DNL by fructose, especially when combined with glucose ingestion. The role of fructose in DNL has been confirmed by a Sevastianova et al. [27] who demonstrated that a 3-week hypercaloric $(+1000 \mathrm{kcal} /$ day) diet enriched with sugars (i.e., candy, fruit juice, and sugar-sweetened beverages) led to an increase in fatty liver and was associated with an increase in the secretion of very low density lipoprotein and an increase in the lipogenic index, (i.e., the ratio of palmitate to linoleate acid), an indirect measure of DNL.

Another study demonstrated the specific steatogenic role of fructose showing that a highly hypercaloric diet, containing a low amount of fructose, did not elicit an increase in liver fat content [24].

Consistently with these results, Maersk et al. [14] compared the effects of ingesting $1 \mathrm{~L} /$ day of a sugar-sweetened beverage with a calorie-matched milk for six months and showed that sugar-sweetened beverage significantly increased liver fat by approximately 1.5 fold, despite similar calorie intake and weight gain.

While the causative role of fructose in hypercaloric diet has a consistent evidence, data on the impact of carbohydrates on liver fat accumulation in the setting of hypo or isocaloric diet are scarce and with contrasting results. One study involving NAFLD patients exposed to hypocaloric diet reported a more evident reduction in liver fat content obtained by reducing carbohydrate intake compared to the reduction of total calories without changing the macronutrient composition of the diet [28]. In contrast, Haufe et al. and Volynets et al. $[29,30]$ suggested that total calorie deficit is the mediating factor for decreasing liver fat and that the carbohydrate intake has little influence. Likewise, also data from isocaloric diets enriched with added sugars did not show an influence on liver fat content which vice-versa was highlighted in subjects assuming hypercaloric high-fructose diets, possibly because of increased substrate availability for DNL.

Along with its specific effect, fructose pathogenetic action is modulated by co-ingestion of other macronutrients. Sobrecases et al. showed in a study comparing a 7-day hypercaloric diet enriched with 
fructose or saturated fatty acids (SFA) that the latter increased liver fat to a greater extent than fructose ( $\sim 86 \%$ vs. $~ 16 \%$ change in hepatic fat content), and that SFA also had an additive effect on hepatic fat accumulation exerted by sugars [26]. On the other hand, supplementation of high-fructose diet with small amount of proteins ( $6.6 \mathrm{~g}$ of essential amino acids/day) leads to an attenuation of hepatic fat accumulation [31]. The beneficial effect of proteins may rely on the augmented fatty acid oxidation due to the increased energy required by the metabolism of amino acids (i.e., gluconeogenesis and cycle of urea) [32].

Finally, the timing of food intake also affects hepatic fat deposition, being more dangerous when consumed between rather than alongside meals [33].

\subsection{Carbohydrates and Cardiovascular Disease}

As for the impact in the development of NAFLD, fructose has been demonstrated to exert a negative effect on CV risk. Interestingly, the amount of added sugar, consumed mainly as HFCS, dramatically increased during the last few decades in Europe and the USA [34] paralleling the augmented prevalence of coronary artery disease (CAD) [35], as supported by a prospective study involving a large female cohort [36]. The association between HCFC and CVD has been confirmed by consistent data. A prospective study involving a cohort of adults in the USA showed that added sugar intake was a risk factor for $\mathrm{CV}$ mortality even when adjusted for conventional cardiovascular risk factors such hypertension and dyslipidemia [37]. Another prospective study involving more than 2600 Iranian subjects, without a history of CV events followed-up for approximately seven years, demonstrated that consumption of food with added fructose, but not natural sugars, was associated with an increased risk of CV events, either myocardial infarction or stroke, and cardiovascular mortality. This result points out that only industrial sweetened products expose to cardiovascular risk, whilst consumption of natural fructose food, like fresh fruit, is safe. In another population-based cohort study of nearly 40,000 adults, daily soft drink consumption increased the risk of CV events by $21 \%$ [38] and in the UK, The National Health Service (NHS) showed that sugar-sweetened beverages significantly increased the risk of stroke by $16 \%$ per one serving per day and coronary heart disease by $20 \%$ [39].

As a consequence, European guidelines for the management of CVD strongly discourage the intake of added sugars in diet, especially sweetened beverages, allowing no more than $25 \mathrm{~g}$ per day [40].

One underlying mechanism which may explain the adverse cardiometabolic outcome of fructose intake is the induction of hepatic lipogenesis and increased circulatory triglycerides levels, as well as the promotion of insulin resistance and oxidative stress [41], as already mentioned in the previous paragraph.

As a confirmation of the deleterious effect of added sugars on cardiovascular risk, in a 4-week prospective randomized study, 24 Hispanic overweight adolescents with hepatic steatosis, all usual high fructose containing beverages drinkers, were randomized to fructose-drinks vs. glucose only beverages. After the intervention period, patients randomized to glucose beverage presented a significant improvement in the cardiometabolic profile (plasma C-reactive protein, insulin-resistance indexes, plasma free fatty acids, and circulating oxydated low-density lipoprotein levels) compared to baseline and to those in the fructose-beverage arm of the study [42].

Conversely to fructose, whole grains seem to have a protective role on cardiovascular risk, mainly due to the high concentration of fibers. Fibers reduce inflammation and reactive oxidation and improve lipid profiles and blood pressure [43]. Ultimately, they inhibit absorption of fats and simple carbohydrates, with improvement of the cardiometabolic profile.

A small randomized clinical trial including a cohort of 300 participants explored the impact of a diet enriched with whole grain on surrogate markers of cardiovascular disease such as blood pressure, cholesterol, and markers of inflammation, and demonstrated a significant improvement of all of them [44]. In addition, a meta-analysis of seven prospective studies showed that an increased consumption of whole grain prompted a $21 \%$ reduction in cardiovascular disease events and mortality [45]. 


\section{Role of Lipids in NAFLD and Cardiovascular Disease}

\subsection{Lipids and NAFLD}

Fatty acids are long hydrocarbon chains and are divided in four categories: saturated fatty acids (SFAs), without double bound between carbon atoms, monounsaturated fatty acids (MUFAs), with only one double bound, polyunsaturated fatty acids (PUFAs), with more than one double bound, and trans fatty acids (TFAs), when the two hydrogen atoms are on opposite sides of the double bond [46]. Among PUFAs, n-3 PUFAs and n-6 PUFAs are essential because humans cannot synthesize them and their precursors (linoleic (18:2 n-6) acid and linolenic acid (18:3n-3) need to be introduced in the diet, to build longer carbon chains [46]. Indeed, if on one hand a great supply of linolenic acid is beneficial, on the other hand, evidence is rising on the need of reducing that of linoleic acid which may favor inflammation and metabolic diseases [47].

In the last century, fatty acids consumption in the daily life has dramatically changed from a diet rich in MUFAs, principally found in olive oil, and, in PUFAs, contained in fish and shellfish, vegetable oils, seeds, and nuts, to a Westernized dietary, where SFAs and TFAs, present in meat and dairy products, prevail [48].

Regarding the consumption of fatty acids, Donnelly et al. demonstrated that $15 \%$ of hepatic fat derived from diet and that this percentage could increase if dietary fat consumption was higher than $30 \%$ of daily energy requirements [49]. Moreover, two epidemiological studies by Toshimitsu at al. and Musso at al. illustrated that NASH patients had a diet richer in saturated fat and cholesterol and poorer in PUFAs compared to the diet of age, gender, and BMI matched controls without NASH [50,51]. Analyzing PUFA intake, a lower consumption of n-3 PUFA and a higher n-6/n-3 ratio were observed in NAFLD and NASH patients compared to controls [23]. Moreover, patients with NAFLD had a depletion in blood and tissue PUFAs content, especially those of marine origin, the n-3 PUFAs (eicosapentaenoic acid (EPA) and docosahexaenoic acid (DHA)) [52,53].

A diet enriched in PUFAs or SFAs has a distinct effect on liver metabolism and visceral fat accumulation because SFAs result in a significant increase in liver and visceral fat compared to PUFAs. Preclinical studies illustrated that a diet rich in n-3 PUFAs, like docosahexaenoic acid (DHA), suppresses diet-induced steatosis, inflammation, and fibrosis [54], along with a positive effect on insulin resistance and serum triglycerides [55,56]. Furthermore, a preclinical study highlighted that, among 3-PUFAs, DHA is superior to eicosapentaenoic acid (EPA) to reduce NASH related inflammation and fibrosis, as well as hepatic fat content $[57,58]$.

The harmful role of SFAs compared to PUFAs has also been confirmed by Bjermo et al. who analyzed two hypercaloric diets, one enriched in n-6 PUFA and the other in SFAs, and showed that, after seven weeks, a similar weight gain was observed, with a dramatically increment in hepatic fat and a two-fold increase in visceral fat only in patients assigned to the SFAs diet compared to the PUFAs diet [59]. In addition, a 10-week randomized clinical trial comparing two isocaloric diets containing $\mathrm{n}-6$ PUFA or SFAs showed an improvement in metabolic status and a decrease in hepatic fat using n-6 PUFAs diet, despite no weight modification [60].

Besides PUFAs, a protective role in fat accumulation has been demonstrated also for MUFAs. In fact, an energy balanced diet with a high proportion of MUFAs was associated with a reduction in hepatic fat in patients with prediabetes [61], type 2 diabetes [62], and NAFLD [63], differently from an energy balanced diet with a very high proportion of SFAs. Indeed, the EASL-EASD-EASO Clinical Practice Guidelines recommended the Mediterranean diet for NAFLD patients in consideration of its high content of MUFAs, present in olive oil and nuts, and the large amount of fruits, legumes, vegetables, and fish and low in red and processed meats and sweets [64].

Multiple checkpoints are influenced by the high-fat diet and oxidative stress is directly associated with an excess of n-6 PUFAs and a low amount of n-3 PUFAs, generating lipid oxidation and NAFLD progression [65]. Firstly, diet modulates gut microbiota, whose metabolic products are delivered to the liver by the portal vein. The alterations of intestinal microbiota, characterized by overgrowth of some 
bacteria phyla and alteration of epithelial barrier permeability, contribute to inflammation, insulin resistance, and fat accumulation. Consequently, these modifications lead to obesity and NAFLD, dysregulating liver functions [66]. Secondly, SFAs promote mitochondrial dysfunction, altering respiratory chain activity and ATP homeostasis, increasing formation of reactive oxygen species (ROS) and inducing apoptosis, consequently impairing phospholipid metabolism and increasing insulin resistance [67]. Lastly, high-fat diet enriched with SFAs was hypothesized to trigger de novo lipogenesis through activation of the peroxisome proliferator-activated receptor (PPAR $\gamma$ )-coactivator-1beta (PGC-1) and the enhancement of transcription in genes involved in lipid metabolism, like the stearoyl-CoA desaturase-1, fatty acid synthase, and diacylglycerol acyltransferase compared to a PUFA diet [68]. On the contrary, n-3 PUFAs control the activity of transcription factors regulating the expression of gene encoding for de novo lipogenesis, fatty acid oxidation, fat uptake from the circulation and VLDL assembly and secretion [54]. Moreover, n-3 PUFAs have also been hypothesized to attenuate fibrosis, possibly by reducing the expression of a broad array of proteins involved in fibrosis [58]. Moreover, DHA has been supposed to act directly on human stellate cells suppressing the expression of Col1A1, the major collagen subtype induced in rodent and human NASH [69]. However, future studies are needed to clarify the role of DHA in hepatic fibrosis.

\subsection{Lipids and Cardiovascular Disease}

Cardiovascular disease (CVD) is the first cause of death and disability worldwide, and diet is one of the most important modifiable risk factors [70].

As described in the previous paragraph, in the last few decades, the daily diet is dramatically changed increasing the proportion of fatty acids, which nowadays represent $28-42 \%$ of total energy consumed by European populations [71], whereas in the past was approximately $20-30 \%$ of total energy [72]. Moreover, the kind of fatty acids in the diet is mutated, n-3 PUFAs intake is reduced, and the ratio between $n-6$ and n-3, which was 1:1, nowadays is dramatically increased to a range between 10:1 and 20:1 [72]. Several studies illustrate that a low ratio between n-6 and n-3 PUFAs has been considered protective for the development of many diseases, such as cardiovascular disease, cancer, and metabolic disease [73]. The cardioprotective action of the eicosanoids derived from n-3 PUFAs is justified by their anti-inflammatory, antiatherogenic, antiarrhythmic, antithrombotic/antiplatelet, antioxidant, hypotensive effects, and the positive action on lipid metabolism [74].

Regarding the food rich in n-3 PUFAs, the consumption of tree nuts, for example, almonds, reduces LDL cholesterol levels by 3 to 19\% [75], while fish consumption has beneficial effects on insulin sensitivity, type 2 diabetes mellitus (T2DM), and lipid profile [76]. In addition, 3-PUFA contained in fish have been associated with a reduced risk for death from coronary heart diseases in healthy individuals [74,77], and in particular the $\alpha$-linolenic acid with a reduced risk of myocardial infarction [78].

According to the literature consensus, healthy adults should have a daily intake of at least $0.5-1 \mathrm{~g} / \mathrm{d}$ n-3PUFAs, equivalent to 2-4 servings per week of fish or a half serving of oily fish, in order to reduce the risk of CVD and improve the features of metabolic syndrome [79]. Indeed, conversely to the past when the total intake of n-3PUFAs exceeded 5-6 g/d [80], nowadays only the traditional Japanese diet contains that level [81].

Moreover, many epidemiological studies demonstrated a low cardiovascular risk associated with Mediterranean diet. In particular, the most important factor is the daily consumption of olive oil, the greatest source of dietary MUFA (about 90\% of all MUFA). In fact, the PREDIMED trial (Primary Prevention of Cardiovascular Disease with a Mediterranean Diet) demonstrated that extra-virgin olive oil or nuts in supplementation to Mediterranean diet reduced the incidence of major cardiovascular events [9].

The protective role of an adequate consumption of olive oil (23 g/day) in the CV risk has already been recognized at the end of the last century by the Food and Drug Administration, addressing olive oil as a qualified dressing able to decrease the risk of coronary heart disease [82]. Indeed, olive oil has 
several beneficial effects on the cardiovascular system: decreases oxidative stress, inhibits oxidation of LDL-cholesterol, cuts-down serum level of triglycerides [83], modulates inflammation [84], reduces blood pressure, delays gastric emptying, decreasing postprandial hyperglycaemia, and improves glycaemic control in diabetic patients [85].

If on one hand MUFAs reduce CV risk, on the other hand, SFAs are associated with an unfavorable metabolic and CV profile, especially because of the increase in low density lipoprotein (LDL) cholesterol. In consideration of that, International Guidelines strongly recommended to reduce the daily consumption of SFAs to a maximum of $5-6 \%$ of the total lipid intake [86].

\section{Role of Proteins in NAFLD and Cardiovascular Disease}

\subsection{Proteins and NAFLD}

Data on the effects of dietary protein in patients with NAFLD are limited and controversial, while, in animal models, results suggest that dietary proteins have a beneficial effect on glucose metabolism, are essential for the regeneration of hepatocytes and could counteract the development of steatosis providing the amino acids needed for the inclusion of fat in lipoproteins and favoring its export from the liver. In addition, the energy requirement for amino acid catabolism could lead to oxidation of hepatic lipids with a consequent increase in fat depletion from the liver $[87,88]$. On the contrary, in population studies, diets enriched in animal proteins, especially in overweight patients, are associated with an increased risk of NAFLD development [89]. However, in the few available controlled trials, diets enriched in proteins were often also low-caloric diets, thus it is not possible to draw any firm conclusions.

Recent studies have highlighted sarcopenia as a risk factor for disease severity in NAFLD. In sarcopenic obesity, defined by the concomitant presence of sarcopenia and obesity, the coexistence of muscle loss and fat accumulation accelerates insulin resistance and inflammation, which lead to atherosclerotic damage and a more severe liver disease (NASH and advanced fibrosis) [90,91].

Very recently, nutritional and behavioral models have been proposed to contrast the increased risk of frailty in the obese, diabetic, and elderly patients ( $>75$ years old) in whom quantities and qualities of various nutrients, including proteins, have been modified compared to younger subjects. These categories of patients should undergo anthropometric measurements and muscle function tests to allow targeted early nutrition interventions (i.e., $1.5 \mathrm{~g} / \mathrm{kg} /$ day of protein intake, $2-3$ hourly food intake with kidney function monitoring) and promotion of physical exercise [92].

\subsection{Proteins and Cardiovascular Disease}

Several large cohort observational and intervention studies in both Western and Asian populations have evaluated whether plant and animal proteins differ in the reduction/promotion of CV risk [93,94]. However, evidence is not definitive because it is difficult to isolate the independent effects of specific proteins from the contribution of other non-protein components in both plant and animal food source, the content of particular amino acids and the interaction with the intestinal microbiome. Red meat, for example, is rich in proteins but also in cholesterol and heme-iron, nutrients associated with the development of CVD through different mechanisms (increase of free fatty acids, oxidative stress, free radical production) $[95,96]$. In addition, as reported above, sarcopenia also, consequent to protein deficiency, is a risk factor for atherosclerosis, thus increasing CV risk [90].

\section{Role of Fibers in the Setting of NAFLD and Cardiovascular Disease}

\subsection{Fibers and NAFLD}

The role of fibers in NAFLD has been studied in animal models and in patients. However, results do not allow for understanding whether the impact of fibers is a direct consequence of the modulation of gut microbiome or if fibers, by themselves, reduce inflammation and thus counteract 
the development of NASH. Fibers can be distinguished into soluble and insoluble, and both can be non-fermentable and fermentable.

Cellulose, a type of insoluble non-fermentable fiber, exhibits protective anti-inflammatory effects through alteration of microbiota [97]. In mice, low-cellulose diets alter the intestinal mucosa by inducing crypt atrophy and reduction of goblet cells, resulting in development of inflammation. Conversely, diets rich in cellulose reduce IL-1 $\beta$ and TNF- $\alpha$, both mediators of inflammation. Furthermore, it has been shown in mouse models of endotoxemia that a diet rich in cellulose acts by reducing the macrophage activity of the spleen and by attenuating the activity of hepatic NF- $\mathrm{kB}$ [98]. In addition, most soluble fibers are fermented by gut microbiota to produce metabolites that impact metabolic processes.

For example, inulin is a type of soluble fiber, the activity of which depends on its chemical structure and the presence of inulin in the diet of overweight, non-diabetic patients, induces a reduction in insulin resistance, coinciding with a change in the gut bacterial population [99]. In addition, $\beta$-glucan supplementation, derived from plant or fungal cell walls, and considered a soluble fiber, reduces insulin resistance, dyslipidemia, and hepatic steatosis jointly with alterations of gut microbiome [100].

\subsection{Fiber and Cardiovascular Disease}

The benefic effect of fibers is documented by the evidence that vegetarian diets reduce atherosclerotic cardiovascular damage with a significant decrease in coronary artery calcifications [101]. In a meta-analysis of nine cohort studies including 222,081 men and women, the overall reduction in coronary heart disease risk was $7 \%$ for each additional portion of vegetable intake per day [102]. Dark green leafy vegetables had the highest reduction in coronary heart disease risk, but it has to be stressed that vegetarian diets are often deficient in many nutrients that have to be supplemented.

\section{Role of Micronutrients in NAFLD and Cardiovascular Disease}

The potential role of micronutrients in both NAFLD and CVD has been debated for years and, although hundreds of papers have been published, sound results are still not available as proven by the fact that very rarely do these compounds reach clinical practice.

The main results reported in literature on bioactive compounds will be described below. The best results on the micronutrients utilization derive from cellular or animal models, while those obtained in patients often are conflicting. In many studies, multiple compounds are combined to enhance the antioxidant, anti-inflammatory, and anti-fibrogenic properties of individual compounds making even more difficult to understand the effect of the individual compounds.

Vitamin E is a fat-soluble vitamin that works as an antioxidant. It was evaluated alone or in combination with other antioxidants such as Sylimarin. The steatohepatitis study (PIVENS) showed that supplementation of $800 \mathrm{IU}$ vitamin $\mathrm{E}$ ( $\alpha$-tocopherol) per day (in people without diabetes) improved steatosis and inflammation and induced resolution of NASH [103]. However, a long-term risk of increased mortality has been demonstrated at these dosages. A recent meta-analysis of 16 controlled studies showed that low doses of vitamin $\mathrm{E}$ alone would reduce the risk of myocardial infarction (RR 0.82; 95\% CI, 0.70-0.96; $p=0.01$ ) [104]. Furthermore, supplementation with Vitamin E is associated with a $2.5 \%$ increase in flow-mediated vasodilation and consequently a reduction in CV risk [105].

Silymarin, one of the most studied nutraceutical of plant origin, has been shown in numerous studies to have several positive effects on the liver and on the cardiovascular system: anti-oxidant (direct scavenger activity, optimization of mitochondrial function), anti-inflammatory (inhibition of NF-kB activity, reduction of the synthesis of proinflammatory cytokines IL-1, IL6, TNFa, TNFb), anti-apoptotic activity (modulation of caspase release) antifibrotic (inhibition of the conversion of stellate cells to fibroblasts, downregulation of target genes) and choleretic (upregulation of the bile salts export pump). Finally, it also exerts a favorable metabolic action by fostering the PPAR-agonist activation and increasing the expression of Glucose transporter-4 (GLUT4) on the cell surface, inhibition of Hydroxyl-Methyl-Glutaryl-Coenzyme-A reductase). 
The studies that have documented the effect of silymarin (or its isoforms) in vivo have used this compound in monotherapy or in association with Vitamin E, and have demonstrated normalization of transaminases, reduction of GGT, and of the degree of steatosis (evaluated by ultrasound), improvement of fasting blood glucose and insulin resistance. However, these positive effects disappear upon discontinuation of the drug [106].

The combined use of vitamin $\mathrm{E}$ and Sylibin, the main active compound of sylimarin, in addition to a low-calorie diet is associated with a reduction of transaminases (ALT and AST), GGT and hepatic steatosis index, while results on HOMA, BMI, and lipids are conflicting. A mixture of vitamin E and C (600 IU/day and $500 \mathrm{mg} /$ day, respectively) given to patients with elevated levels of ALT and biopsy-proven NAFLD that followed a weight-reducing diet showed a significative reduction of transaminases and of fibrosis [107]. It has also been reported that addition of atorvastatin to vitamin C and E would reduce the risk of fatty liver development [108].

\section{Vitamin D}

Vitamin D is a fat soluble secosteroid hormone, about $10 \%$ derived from the diet, while $90 \%$ from the cutaneous conversion of 7-dehydrocholesterol to cholecalciferol due to exposure to ultraviolet $\mathrm{B}$ rays.

Animal and cellular studies showed that vitamin D plays a fundamental role in the metabolism of minerals, but also in inflammation, regulation of the immune response and cell differentiation, with impact on the liver and on the cardiovascular system [109].

An interaction between vitamin D and NAFLD has been described. Recently, some literature data showed a higher prevalence of vitamin D deficiency in NAFLD, with vitamin D playing a role in NAFLD and cardiovascular disease through increasing insulin sensitivity, reducing inflammation of the adipose tissue, reducing liver inflammation and fibrosis [110]. However, it is still debated whether patients with NAFLD have a higher prevalence of vitamin D deficiency than people without steatosis and the effectiveness of adding vitamin D on NAFLD histological damage [111].

The decrease in sun exposure and the modern lifestyle, besides the reduction of the hepatic and renal hydroxylation capacity with aging, causes vitamin D deficiency in a large part of the population. Vitamin D deficiency has been reported in chronic liver diseases of different etiology, and it has even been associated with hepatic decompensation in liver cirrhosis. However, the most reliable data demonstrate effectiveness of vitamin D supplementation when associated with diet, thus it is not clear which is the real impact of vitamin D by itself.

\section{Vitamin K}

The role of vitamin $\mathrm{K}$ on CV alterations is documented in cohorts of patients with CVD, hypertension, and in the general population. The Multi-Ethnic Study of Atherosclerosis (MESA) demonstrated an increased prevalence of CAC in patients with a low intake of vitamin K1 with diet, especially in patients on antihypertensive drugs. A population-based study of 4807 participants found that the incident risk for chronic heart disease was reduced by Vitamin K [112,113].

\section{Curcumin}

Curcumin is an insulin sensitizing agent extracted from Curcuma longa, whose effect on NAFLD is reported in few preclinical and clinical studies. Curcumin would reduce some altered parameters of NAFLD including transaminases, abdominal circumference, and especially ultrasound steatosis. However, given the high dosage needed to obtain the effect, the only recent availability of pharmaceutical preparations with a known dose of the drug and finally the presence of a few randomized controlled trials with adequate numbers of patients, make these data still preliminary $[114,115]$.

Curcumin displays a role also in CVD. In fact, in mice models, it significantly attenuates collagen deposition and inhibits cardiac fibroblast proliferation and migration after coronary damage [116]. In a study of 121 patients, curcumin reduced myocardial infarction after coronary artery bypass graft from $30 \%$ to $13 \%$ [117]. 
The potential effect on NAFLD of the administration of the mixed extracts obtained from natural sources was also evaluated. In general, these mixtures are very rich in phenolic compounds, carotenoids, vitamins, and minerals. Among them, some preparations were used more rigorously. Most of the beneficial effects of curcumin or its bioactive agents are still limited to preclinical studies in animal models [118], while randomized, controlled studies in humans have not reported conclusive results even for the small sample size [119].

\section{Polyphenols}

Polyphenols derive from plant metabolism and are divided into flavonoids and non-flavonoids and are contained in many natural compounds, as vegetables, cereals and fruits), as well as in tea, coffee, red wine, and beer. Normally, the daily diet intake is around 800-1300 mg [120] and their supplementation is essential because of their antioxidant, anti-inflammatory, anti-mutagenic and immunomodulatory action. As a consequence, a diet rich in polyphenols would reduce dyslipidemia and oxidative stress [121]. There are numerous studies in animal models: polyphenols can decrease the transcription of SREBP-1c and determine an increase in the transcription of PPAR-a, reducing insulin resistance and inflammation. However, clinical data on patients are conflicting. Some clinical studies which evaluated the effect of anthocyanins, phenolic acids, and catechins in NAFLD, found a reduction in biomarkers of hepatocyte apoptosis, ALT levels and liver fat content, evaluated by CT [122]. Resveratrol is currently one of the most evaluated polyphenols and some studies have been conducted in NAFLD with opposite results, showing a transient reduction in ALT and AST and CK18, but not of fibrosis [123].

It is therefore possible to hypothesize, on the basis of the data reported in the literature, that catechins and anthocyanins could have some effect on steatosis; however, data need to be confirmed in further research.

\section{Caffeine}

Several studies have evaluated the efficacy of caffeine, an alkaloid derivative of xanthine, which is the main compound in coffee, and of coffee consumption itself, in NAFLD. A reduction in the risk of developing NAFLD of approximately $30 \%$ has been described. In addition, a reduction in fibrosis has also been reported, the mechanism of which could be linked to inhibition of adhesion and activation of hepatic stellate cells. However, the definition of regular coffee consumption varies widely between studies and this may represent a limitation of the results presented in different meta-analyses $[124,125]$. It is also unclear whether the beneficial effect of caffeine/coffee is due to an association rather than a real causal mechanism. Finally, it is possible that other compounds present in coffee, including polyphenols and melanoidins, are the real culprits.

\section{Genetics and Diet in NAFLD and Cardiovascular Disease}

As already said, NAFLD is characterized by metabolic alterations, an incorrect diet, mainly rich in SFA and sugars, and physical inactivity. In addition, patients with NAFLD and metabolic alterations are exposed to high cardiovascular risk and a high rate of $\mathrm{CV}$ events. However, not all patients with a risky metabolic profile or unhealthy lifestyle develop hepatic steatosis or a cardiovascular disease.

\subsection{Genetic Bases of NAFLD and CV Risk}

The role of genetic predisposition is well established in the pathogenesis of NAFLD, and the strong heritability component is sustained by epidemiological, familial, and twin studies [126]. Several single nucleotide polymorphisms (SNPs) in genes involved in lipid metabolism play a role in the onset of NAFLD and progression towards advanced forms of liver damage. The patatin-like phospholipase domain-containing 3 (PNPLA3) is the major determinant of hepatic fat content and of its progression $[127,128]$ and leads to accumulation of a mutated protein, with an impaired function in lipase activity on hepatocellular lipid droplets, thus favoring triglycerides accumulation within 
the liver. Another genetic determinant in NAFLD is the variant in a transmembrane 6 superfamily member 2 gene (TM6SF2) which predisposes to an increased hepatic fat content because of retention of lipids and impairment in very low-density lipoprotein (VLDL) release by the liver [129]. In addition, mutations in the membrane bound O-acyltransferase domain-containing 7 gene (MBOAT7) foster liver fat accumulation and inflammation. In fact, this gene encodes for an enzyme localized on the mitochondria-associated membrane, where lipid droplets formation occurs, thus regulating the desaturation of membranes phospholipids and the production of arachidonic acid, which is involved in inflammatory processes [130]. Finally, the glucokinase regulatory protein (GCKR) gene, which modulates the glucose influx into the hepatocytes and the de novo lipogenesis, is involved in NAFLD development [131]. However, less than $10 \%$ of inherited variability is explained by these common variants.

Likewise, a large number of genes and their variants may influence the CV risk by different routes. Among them, the 5-10-Methylene tetrahydrofolate reductase (MTHFR) and the Methionine synthase (MTR), both regulating homocysteine metabolism, an atherogenic and prothrombotic protein, have been related with an increased risk of coronary artery disease (CAD) [132,133]. Similarly, the LDL receptors gene which is involved in low-density lipoprotein (LDL) and triglyceride metabolism and the LIPC gene (hepatic lipase C), the major determinant of plasma HDL concentration, are linked to increased prevalence of myocardial infarction and CAD in the general population $[134,135]$. Finally, the apolipoprotein APO-A and APO-E family gene, encoding key regulators of plasma lipids, have a significant impact on CAD [136]. The possible mechanisms and interactions between liver, cardiovascular, and nutrient damage are shown in Figure 1.

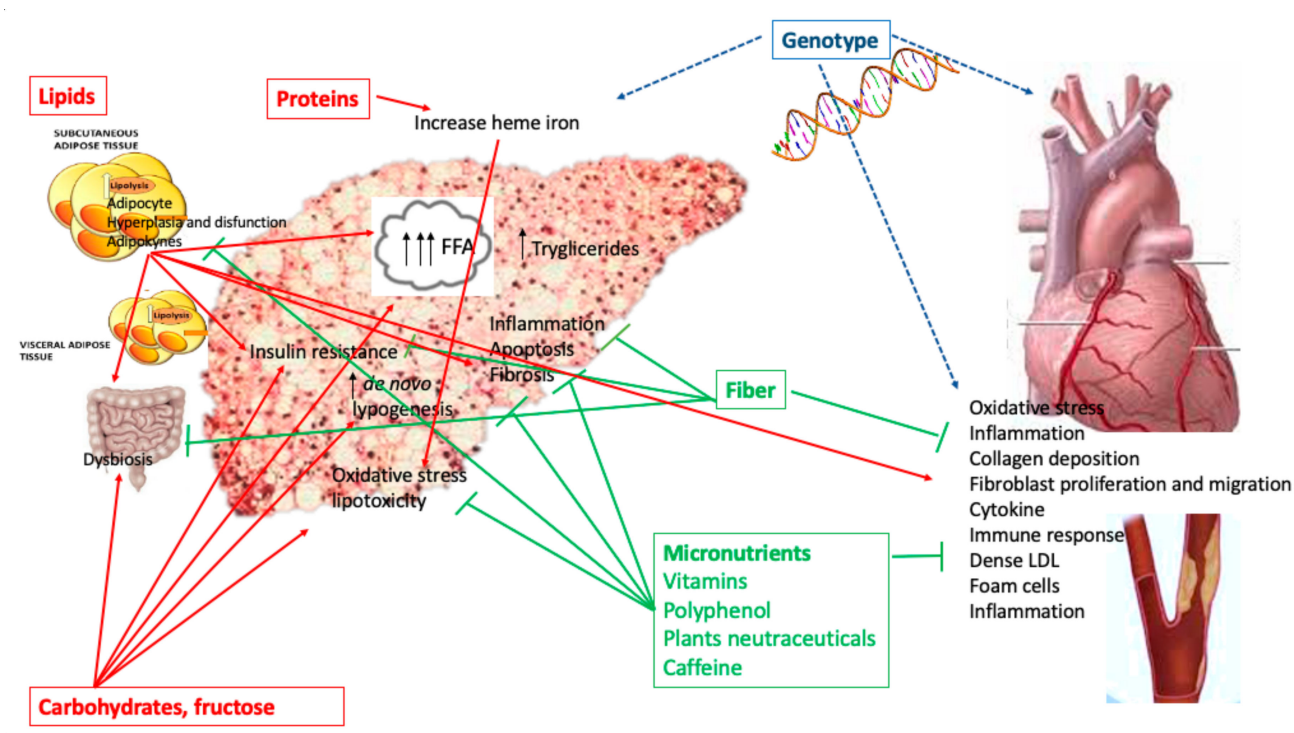

Figure 1. Potential multiple distinct and interrelated mechanisms by which nutrients promote (red line) or prevent (green line) liver and cardiovascular damage. Influence of genetics on NAFLD and cardiovascular damage (blue line).

\subsection{Nutritional Genomics or Nutrigenomics}

Besides pure genetic bases of diseases, in the last few years, evidence is accumulating on the complex interplay between genetic predisposition and environmental influences, particularly diet, in the development of NAFLD as well as in the increase in cardiovascular risk, possibly suggesting common etiopathogenetic pathways linking both hepatic and CVD.

Therefore, since 2013, the term nutritional genomics or "nutrigenomics" has been coined, defining the interaction between cellular, genetic processes, and nutritional environment [137]. Nutrigenomic has the aim of exploring the effect of diet on disease development by modulating the expression of an individual's genetic pattern. 
Three main fields of study cover this interaction: (1) the genetic variability response towards nutrition, named nutrigenetics; (2) the effect of nutrients on DNA metabolism; and (3) the effect of nutrients on genetic expression.

\subsubsection{Nutrigenetic: Genetic Variability Response towards Nutrition}

The most widely studied gene which interacts with the environment in NAFLD is represented by PNPLA3. In fact, accumulation of the protein encoded by the mutated gene is triggered by acquired factors, like obesity [138], alcohol consumption [139], and diet, especially with a high content in carbohydrates [140]. A nutrigenetic analysis in a cohort of Italian adolescents showed that hepatic triglycerides accumulation was related to carbohydrate and sugar intake in the homozygous mutated group but not in the wild type group [141]. The rationale of this influence relies on carbohydrate-mediated upregulation of PNPLA3, which in turn favors the accumulation of the pathological protein on the surface of lipid droplets.

Indeed, PNPLA3 is influenced also by fatty acids in the diet, particularly n-6/n-3 PUFA [142]. In 127 Caucasian adolescents with steatosis evaluated by MRI, increased transaminases and free fatty acids were associated with a diet with a high n-6/n-3 PUFA ratio, but only in patients homozygous for the mutated PNPLA3 variable. This result is possibly related to the impaired hydrolyzing function of PNPLA3, with accumulation of hepatic triglycerides and metabolites of omega 6 PUFA with pro-inflammatory action (Santoro, 2012) [142]. In addition, patients with NAFLD and mutated PNPLA3 seem to have no response in terms of reduction of the novo lipogenesis and improvement in transaminases by n-3 PUFA supplementation in the diet [143].

In addition, mutated patients for the TM6SF2 and MBOAT7 genes are affected by diet. Carriers of the mutated TM6SF2 allele present better fasting and postprandial lipid profiles, with consequent reduction of circulating atherogenic lipoproteins even after a high fat challenge compared to the wild types $[144,145]$. As regarding MBOAT7, besides the mutations associated with genetic predisposition, its expression may be downregulated also by diet-induced hyperinsulinemia [146], thus fostering the accumulation of phosphatidylinositol species which are used as substrates for the synthesis and hepatic deposition of saturated and mono-unsaturated triglycerides. Finally, several studies have shown that mutated allele carriers of GCKR present lower fasting glucose and insulin concentrations after a whole-grain supplementation independently of other metabolic risk factors, as well as to dietary restrictions [147].

In the setting of CVD, the MTHFR gene suffers from folic acid deficiency, being predisposed to systemic inflammation and prothrombotic events [132]. Another gene named Transcription factor 7-like-2 (TCF7L2) and implicated in type 2 diabetes mellitus interacts with the Mediterranean diet in the reduction of stroke risk [148].

The benefit of PUFAs in CVD is widely known [149]. The effect of PUFA intake on HDL cholesterol concentration is mainly modulated by the APOA1 (main apolipoprotein of HDL), thus it was shown that PUFAs consumption was associated with higher HDL cholesterol concentration depending on APOA1 polymorphism [150]. In addition, the APO-E4 polymorphism has been associated with the development of CAD. A study examining the effect of a quercetin supplementation (flavonoid glycosides) in a cohort of overweight-obese individuals with metabolic syndrome showed a significant reduction in HDL in the subgroup of patients carrying the APO-E4 polymorphism, differently from the APO-E3 carriers [151]. In another population-based study involving nearly 2000 subjects, the APO-E3 and APO-E4 genotypes were significantly associated with a high risk of acute myocardial infarction in patients treated with high saturated fatty acids $(>10 \%)$ diet compared with APO-E2 carriers [152].

\subsubsection{Effect of Nutrients on DNA Metabolism}

Studies of the effect of micronutrients on DNA metabolism have shown that several micronutrients (especially calcium, folate, nicotinic acid, vitamin E, retinol) are necessary for DNA homeostasis, 
being cofactors of a several enzymes essential to DNA synthesis and repair [153], whereas others, as the TFAs, favor DNA damage [154]. Their depletion may prompt unfavorable DNA modifications.

In addition, telomeres shortening is typical of aging and of many chronic diseases, including NAFLD [155] and cardiovascular disease [156]. Diet has an impact on telomeres homeostasis, with vegetables, fibers, and omega- 3 fatty acids preventing telomeres shortening, whereas saturated fatty acids, processed meat, or carbohydrates with a high glycemic index favoring it $[157,158]$.

\subsubsection{Effect of Nutrients on Genetic Expression}

The study of the effect of nutrients on gene expression primary identifies the transcription factors that are sensitive to a specific nutrient and their target genes, then the signaling pathways activated by these transcription factors and the possible proteins and metabolites created, detected by "omics" techniques, and finally the organ-specific response to nutrients [159].

Many transcription factors are susceptible to diet influences. In particular, the peroxisome proliferator-activated receptor (PPAR) family, which is involved in glucose and lipid metabolism, adipocyte differentiation, and inflammatory response, is one of the most widely studied. In fact, each PPAR family member $\alpha, \delta$, and $\gamma$ is responsive to specific dietary fatty acids (PUFAs, monounsaturated fatty acids, and SFAs) $[160,161]$. Interestingly, PPAR $\gamma$ expression induced by omega 3 PUFA can increase the lipid storage capacity of adipose tissue along with hepatic fatty acid oxidation and reduce systemic inflammation, with consequent improvement in insulin sensitivity, hepatic steatosis, and CV risk. Polymorphisms in PPAR- $\gamma 2$, the most important form associated with CVD, have been analyzed in a 2-year nutritional intervention with a Mediterranean-style diet vs. conventional low-fat diet in 774 patients at high-cardiovascular risk [162]. The results showed that only carriers of the mutated allele allocated in the low-fat diet and not in the Mediterranean diet arm significantly increased waist circumference compared with non-mutated participants. Therefore, it could be speculated that the Mediterranean diet could mitigate the adverse metabolic effects of mutation in PPAR-g2 gene in a high-cardiovascular risk population.

\subsection{Epigenetic, Diet, NAFLD, and CVD}

Along with genetic predisposition to NAFLD and CVD, disease development and natural history are also modulated by epigenetic mechanisms, heritable but reversible phenomena that modify gene transcription without altering DNA sequence [163].

The epigenetic modulation of gene expression includes (a) DNA methylation; (b) chromatin remodeling (histone modifications); and (c) microRNAs formation (small particles of non-coding RNA with specific functionality). Epigenetic modifications affect hepatic lipid metabolism, insulin resistance, mitochondrial function, and oxidative stress and diet may modulate all these $[164,165]$.

(a) Some nutrients, such as choline, methionine, folate and vitamin B12 are considered "methyl-donor" promoting methylation of DNA and histones. Actually, DNA methylation, considered a key factor in the progression from simple steatosis to NASH and in triglycerides metabolism, may be increased by dietary deficiency of choline, betaine, B12, and folate. In fact, their supplementation is associated with an increase in the hepatic efflux of triglycerides [166]; conversely, their deficiency promotes hepatic triglycerides accumulation by fostering over-expression of genes involved in fatty acids synthesis [167]. In addition, in a rodent model, supplementation of methyl-donor micronutrients to a high-fat-sucrose diet mitigated the effect on triglycerides accumulation within the liver through a hypermethylation of a key enzyme involved in fatty acids synthesis [168]. In vivo studies showed the epigenetic effect of these nutrients, altering endothelial cell function, and inflammation processing, with consequent plaque formation and increased CV risk [169].

(b) Post-translational modification of histones is essential to define chromatin architecture and thus gene accessibility. In response to caloric restriction, Sirt1, a key enzyme involved in DNA repair, induces histone and non-histone deacetylation of genes involved in insulin-resistance and inflammation of the adipose tissue, promoting gluconeogenesis and fatty acid oxidation in the liver [170]. A histone 
acetyltransferase inhibitor, the tannic acid, a plant-derived polyphenol, has been demonstrated to block the hyperacetylation of histones of the promoter of DNL, thus reducing its activity and hepatic fat accumulation [171]. Likewise, SFAs, produced by fermentation of polysaccharide by gut microbiota, also inhibit histone deacetylases with consequent impairment in metabolic and inflammatory processes [172].

(c) Alteration of mRNA stability may arise through formation of small RNA molecules called microRNAs which bind to transcriptional mRNA turning into post-transcriptional repression of targeted protein-coding genes. Unhealthy diets may foster NAFLD development by altering miRNAs. One of the most represented in liver and hallmark of fat accumulation and steatosis severity, the miR-122 has been shown to be responsive to diet either in vitro or in vivo models and in humans. In particular, a high-fat-diet upregulated miR-122 with consequent promotion of lipogenesis within the liver [173]. However, non-conclusive data were reported on plant-derived dietary microRNAs which may potentially cross the intestinal and once in the bloodstream regulate host gene expression involved in cardiometabolic risk [174]. On the other hand, host derived small RNAs regulating processes of relevance to cardiometabolic risk are altered by dietary intervention [175].

Interestingly, epigenetic mechanisms may arise during the gestational period, as the fetus liver may be "primed" with unhealthy metabolic pattern by mother over-nutrition, as well as in post-natal period and over time with aging. For example, in pregnant women with a diet rich in fat, a state of chronic-low grade inflammatory arises in the placenta as well in the fetal organs, including the liver, contributing to steatosis development [176].

Based on this background, the role of gene-diet interaction in patients with NAFLD is crucial because, by modifying dietary pattern in genetically predisposed individuals, it could be possible to modulate specific clinical outcome. The long-term hypothetical objective could be the tailored therapy based also on a personalized nutritional approach.

\section{Preliminary Data}

In order to evaluate the role of diet on clinical presentation and cardiovascular alterations in patients with NAFLD, we enrolled 154 newly diagnosed, consecutive, untreated NAFLD patients (M/F 112/42 mean age $49 \pm 12$ years), who were administered a semi-quantitative food-frequency questionnaire (dietary record including 118 food items covering seven days) to calculate energy and nutrients intake. Steatosis, carotid intima-media thickness (IMT), and plaques were evaluated by ultrasonography; diastolic dysfunction $(\mathrm{E} / \mathrm{A}<1)$, left ventricular mass, and epicardial adipose thickness (EAT) by echocardiography. Twenty-three (15\%) patients had "lean" NAFLD (BMI $<25 \mathrm{~kg} / \mathrm{m}^{2}$ ). Moderate to severe steatosis was present in $61 \%$, IMT above normal value in $13 \%$, carotid plaques in $28 \%$, and E/A < 1 in 39\%; mean EAT was $5.8 \pm 4 \mathrm{~mm}$. Total calories and macro-nutrient intake (g/day) were: $1705 \pm 5750 \mathrm{kcal}$; proteins $98 \pm 46$, fat $65 \pm 32$ (saturated $23 \pm 14$; PUFA $10 \pm 5$; monounsaturated $25 \pm 12$ ), carbohydrates $164 \pm 75$ (simple sugar $64 \pm 35$ ), fibers $23 \pm 14$. Interestingly, no difference in daily dietary composition of nutrients and total Kcal between lean and overweight patients was observed, despite a higher prevalence of metabolic comorbidities and moderate-severe steatosis in the latter. Among nutrients, fructose intake was significantly higher in patients with plaques $(p=0.03)$ and vitamin $\mathrm{E}$ lower in those with $\mathrm{E} / \mathrm{A}<1(p=0.01)$. At multivariate analysis adjusted for age, sex, and BMI, diet fat content was significantly associated with dyslipidemia (OR 1.2, 95\%CI 1-1.4, $p=0.04$ ), fat, and carbohydrate with moderate-severe US steatosis (OR 1.2, 95\%CI 1.03-1.5, $p=0.01$ ).

\section{Conclusions}

In conclusion, both diet and genetic factors strongly impact on both NAFLD and cardiovascular damage, either alone or when interacting.

In particular, solid data in literature highly stress the potentially negative role of an incorrect diet, rich in fructose and added sugars, as well as in n-6 PUFAs and SFAs, in the development of both hepatic and cardiovascular diseases. Therefore, the elimination of soft drinks and sweetened bakery 
products, along with dairy and animal fat, from daily consumption, preferring complex carbohydrates, possibly whole grain, fibers, olives, and vegetable oils, fish, seeds, and nuts rich in MUFAs, and n-3 PUFAs is highly advisable. Indeed, one of the most recommended diet for patients with NAFLD is the Mediterranean diet, which has also been demonstrated to dramatically reduce cardiovascular events. If the role of carbohydrates and fat is well established, that of proteins and micronutrients (especially vitamins) is not completely elucidated, despite a protective role mediated by antioxidant and anti-inflammatory actions having been suggested.

Along with the diet, some genetic bases, either congenital or caused by environmental actions (i.e., epigenetic), have been implicated in the pathogenesis and progression of hepatic and cardiovascular disease. Even more interestingly, in the last few years, evidence is accumulating on the interplay between genetic predisposition and environmental influences, particularly diet, in the setting of NAFLD and cardiovascular disease, coining the new concept of nutritional genomics or nutrigenomics.

Based on this evidence, an accurate correction of patients' diet along with the understanding of the gene-diet interaction become crucial because modification of dietary pattern in genetically predisposed individuals could modulate specific clinical outcomes, either the metabolic, hepatological, or cardiovascular ones, so that a personalized nutritional therapy should be speculated on in the future.

Author Contributions: R.L. revised the literature, focusing on the full text regarding diet and genetic influence on NAFLD development and increased cardiovascular risk; R.L., F.I., and G.P. wrote the draft of the manuscript; S.F. and A.L.F. were involved in the critical revision of the manuscript into its final form and contributed to the review for important intellectual content. All authors have read and agreed to the published version of the manuscript.

Funding: Ministry of Health RF 02-358519 "Early atherosclerosis in patients with steatosis and with chronic hepatitis C: role of visceral adiposity, procoagulant imbalance and endothelial dysfunction in vascular damage".

Conflicts of Interest: The authors declare no conflict of interest.

\section{Abbreviations}

$\begin{array}{ll}\text { NAFLD } & \text { non-alcoholic fatty liver disease } \\ \text { NASH } & \text { non-alcoholic steatohepatitis } \\ \text { CVD } & \text { cardiovascular disease } \\ \text { FFAs } & \text { free fatty acids } \\ \text { TFA } & \text { trans fatty acids } \\ \text { PNPLA3 } & \text { patatin-like phospholipase domain containing 3 } \\ \text { TM6SF2 } & \text { transmembrane 6 superfamily member 2 } \\ \text { MBOAT7 } & \text { membrane bound O-acyltransferase domain-containing 7 } \\ \text { HFCS } & \text { high fructose corn syrup } \\ \text { DNL } & \text { de novo lipogenesis } \\ \text { CAD } & \text { coronary artery disease } \\ \text { APO } & \text { apolipoprotein } \\ \text { SFAs } & \text { saturated fatty acids } \\ \text { MUFA } & \text { monounsaturated fatty acids } \\ \text { PUFA } & \text { unsaturated fatty acids } \\ \text { MTHFR } & \text { methylene tetrahydrofolate reductase } \\ \text { DHA } & \text { docosahexaenoic acid } \\ \text { EPA } & \text { eicosapentaenoic acid } \\ \text { PPAR } & \text { peroxisome proliferator activated receptor } \\ \text { HFCS } & \text { high fructose corn syrup } \\ \text { GLUT4 } & \text { glucose transporter-4 }\end{array}$




\section{References}

1. Byrne, C.D.; Targher, G. NAFLD: A multisystem disease. J. Hepatol. 2015, 62, S47-S64. [CrossRef] [PubMed]

2. Eslam, M.; Sanyal, A.J.; George, J.; International Consensus Panel. MAFLD: A Consensus-Driven Proposed Nomenclature for Metabolic Associated Fatty Liver Disease. Gastroenterology 2020, 158, 1999-2014.e1. [CrossRef] [PubMed]

3. Ekstedt, M.; Hagstrom, H.; Nasr, P.; Fredrikson, M.; Stal, P.; Kechagias, S.; Hultcrantz, R. Fibrosis stage is the strongest predictor for disease-specific mortality in NAFLD after up to 33 years of follow-up. Hepatology 2015, 61, 1547-1554. [CrossRef] [PubMed]

4. Valbusa, F.; Bonapace, S.; Agnoletti, D.; Scala, L.; Grillo, C.; Arduini, P.; Turcato, E.; Mantovani, A.; Zoppini, G.; Arcaro, G.; et al. Nonalcoholic fatty liver disease and increased risk of 1-year all-cause and cardiac hospital readmissions in elderly patients admitted for acute heart failure. PLoS ONE 2017, 12, e0173398. [CrossRef]

5. Bugianesi, E.; Moscatiello, S.; Ciaravella, M.F.; Marchesini, G. Insulin resistance in nonalcoholic fatty liver disease. Curr. Pharm. Des. 2010, 16, 1941-1951. [CrossRef]

6. Eslam, M.; Valenti, L.; Romeo, S. Genetics and epigenetics of NAFLD and NASH: Clinical impact. J. Hepatol. 2018, 68, 268-279. [CrossRef]

7. Dongiovanni, P.; Petta, S.; Maglio, C.; Fracanzani, A.L.; Pipitone, R.; Mozzi, E.; Motta, B.M.; Kaminska, D.; Rametta, R.; Grimaudo, S.; et al. Transmembrane 6 superfamily member 2 gene variant disentangles nonalcoholic steatohepatitis from cardiovascular disease. Hepatology 2015, 61, 506-514. [CrossRef]

8. Godos, J.; Federico, A.; Dallio, M.; Scazzina, F. Mediterranean diet and nonalcoholic fatty liver disease: Molecular mechanisms of protection. Int. J. Food. Sci. Nutr. 2017, 68, 18-27. [CrossRef]

9. Estruch, R.; Ros, E.; Salas-Salvado, J.; Covas, M.I.; Corella, D.; Aros, F.; Gómez-Gracia, E.; Ruiz-Gutiérrez, V.; Fiol, M.; Lapetra, J.; et al. Primary Prevention of Cardiovascular Disease with a Mediterranean Diet Supplemented with Extra-Virgin Olive Oil or Nuts. N. Engl. J. Med. 2018, 378, e34. [CrossRef]

10. Schwarz, J.M.; Noworolski, S.M.; Wen, M.J.; Dyachenko, A.; Prior, J.L.; Weinberg, M.E.; Herraiz, L.A.; Tai, V.W.; Bergeron, N.; Bersot, T.P.; et al. Effect of a High-Fructose Weight-Maintaining Diet on Lipogenesis and Liver Fat. J. Clin. Endocrinol. Metab. 2015, 100, 2434-2442. [CrossRef]

11. Strable, M.S.; Ntambi, J.M. Genetic control of de novo lipogenesis: Role in diet-induced obesity. Crit. Rev. Biochem. Mol. Biol. 2010, 45, 199-214. [CrossRef] [PubMed]

12. Softic, S.; Cohen, D.E.; Kahn, C.R. Role of Dietary Fructose and Hepatic De Novo Lipogenesis in Fatty Liver Disease. Dig. Dis. Sci. 2016, 61, 1282-1293. [CrossRef] [PubMed]

13. Jornayvaz, F.R.; Shulman, G.I. Diacylglycerol activation of protein kinase Cepsilon and hepatic insulin resistance. Cell Metab. 2012, 15, 574-584. [CrossRef] [PubMed]

14. Maersk, M.; Belza, A.; Stodkilde-Jorgensen, H.; Ringgaard, S.; Chabanova, E.; Thomsen, H.; Pedersen, S.B.; Astrup, A.; Richelsen, B. Sucrose-sweetened beverages increase fat storage in the liver, muscle, and visceral fat depot: A 6-mo randomized intervention study. Am. J. Clin. Nutr. 2012, 95, 283-289. [CrossRef] [PubMed]

15. Rosset, R.; Surowska, A.; Tappy, L. Pathogenesis of Cardiovascular and Metabolic Diseases: Are Fructose-Containing Sugars More Involved Than Other Dietary Calories? Curr. Hypertens. Rep. 2016, 18, 44. [CrossRef]

16. Santos-Marcos, J.A.; Perez-Jimenez, F.; Camargo, A. The role of diet and intestinal microbiota in the development of metabolic syndrome. J. Nutr. Biochem. 2019, 70, 1-27. [CrossRef]

17. Jia, Q.; Xia, Y.; Zhang, Q.; Wu, H.; Du, H.; Liu, L.; Wang, C.; Shi, H.; Guo, X.; Liu, X.; et al. Dietary patterns are associated with prevalence of fatty liver disease in adults. Eur. J. Clin. Nutr. 2015, 69,914-921. [CrossRef]

18. Lim, J.S.; Mietus-Snyder, M.; Valente, A.; Schwarz, J.M.; Lustig, R.H. The role of fructose in the pathogenesis of NAFLD and the metabolic syndrome. Nat. Rev. Gastroenterol. Hepatol. 2010, 7, 251-264. [CrossRef]

19. Papandreou, D.; Karabouta, Z.; Pantoleon, A.; Rousso, I. Investigation of anthropometric, biochemical and dietary parameters of obese children with and without non-alcoholic fatty liver disease. Appetite 2012, 59, 939-944. [CrossRef]

20. Ma, J.; Fox, C.S.; Jacques, P.F.; Speliotes, E.K.; Hoffmann, U.; Smith, C.E.; Saltzman, E.; McKeown, N.M. Sugar-sweetened beverage, diet soda, and fatty liver disease in the Framingham Heart Study cohorts. J. Hepatol. 2015, 63, 462-469. [CrossRef] 
21. Abdelmalek, M.F.; Suzuki, A.; Guy, C.; Unalp-Arida, A.; Colvin, R.; Johnson, R.J.; Diehl, A.M. Increased fructose consumption is associated with fibrosis severity in patients with nonalcoholic fatty liver disease. Hepatology 2010, 51, 1961-1971. [CrossRef] [PubMed]

22. Mager, D.R.; Iniguez, I.R.; Gilmour, S.; Yap, J. The effect of a low fructose and low glycemic index/load (FRAGILE) dietary intervention on indices of liver function, cardiometabolic risk factors, and body composition in children and adolescents with nonalcoholic fatty liver disease (NAFLD). JPEN J. Parenter. Enteral. Nutr. 2015, 39, 73-84. [CrossRef] [PubMed]

23. Cortez-Pinto, H.; Jesus, L.; Barros, H.; Lopes, C.; Moura, M.C.; Camilo, M.E. How different is the dietary pattern in non-alcoholic steatohepatitis patients? Clin. Nutr. 2006, 25, 816-823. [CrossRef] [PubMed]

24. Le, K.A.; Faeh, D.; Stettler, R.; Ith, M.; Kreis, R.; Vermathen, P.; Boesch, C.; Ravussin, E.; Tappy, L. A 4-wk high-fructose diet alters lipid metabolism without affecting insulin sensitivity or ectopic lipids in healthy humans. Am. J. Clin. Nutr. 2006, 84, 1374-1379. [CrossRef]

25. Ngo Sock, E.T.; Le, K.A.; Ith, M.; Kreis, R.; Boesch, C.; Tappy, L. Effects of a short-term overfeeding with fructose or glucose in healthy young males. Br. J. Nutr. 2010, 103, 939-943. [CrossRef]

26. Sobrecases, H.; Le, K.A.; Bortolotti, M.; Schneiter, P.; Ith, M.; Kreis, R.; Boesch, C.; Tappy, L. Effects of short-term overfeeding with fructose, fat and fructose plus fat on plasma and hepatic lipids in healthy men. Diabetes Metab. 2010, 36, 244-246. [CrossRef]

27. Sevastianova, K.; Santos, A.; Kotronen, A.; Hakkarainen, A.; Makkonen, J.; Silander, K.; Peltonen, M.; Romeo, S.; Lundbom, J.; Lundbom, N.; et al. Effect of short-term carbohydrate overfeeding and long-term weight loss on liver fat in overweight humans. Am. J. Clin. Nutr. 2012, 96, 727-734. [CrossRef]

28. Browning, J.D.; Baker, J.A.; Rogers, T.; Davis, J.; Satapati, S.; Burgess, S.C. Short-term weight loss and hepatic triglyceride reduction: Evidence of a metabolic advantage with dietary carbohydrate restriction. Am. J. Clin. Nutr. 2011, 93, 1048-1052. [CrossRef]

29. Haufe, S.; Engeli, S.; Kast, P.; Bohnke, J.; Utz, W.; Haas, V.; Hermsdorf, M.; Mähler, A.; Wiesner, S.; Birkenfeld, A.L.; et al. Randomized comparison of reduced fat and reduced carbohydrate hypocaloric diets on intrahepatic fat in overweight and obese human subjects. Hepatology 2011, 53, 1504-1514. [CrossRef]

30. Volynets, V.; Machann, J.; Kuper, M.A.; Maier, I.B.; Spruss, A.; Konigsrainer, A.; Bischoff, S.C.; Bergheim, I. A moderate weight reduction through dietary intervention decreases hepatic fat content in patients with non-alcoholic fatty liver disease (NAFLD): A pilot study. Eur. J. Nutr. 2013, 52, 527-535. [CrossRef]

31. Theytaz, F.; Noguchi, Y.; Egli, L.; Campos, V.; Buehler, T.; Hodson, L.; Patterson, B.W.; Nishikata, N.; Kreis, R.; Mittendorfer, B.; et al. Effects of supplementation with essential amino acids on intrahepatic lipid concentrations during fructose overfeeding in humans. Am. J. Clin. Nutr. 2012, 96, 1008-1016. [CrossRef] [PubMed]

32. Veldhorst, M.A.; Westerterp-Plantenga, M.S.; Westerterp, K.R. Gluconeogenesis and energy expenditure after a high-protein, carbohydrate-free diet. Am. J. Clin. Nutr. 2009, 90, 519-526. [CrossRef] [PubMed]

33. Koopman, K.E.; Caan, M.W.; Nederveen, A.J.; Pels, A.; Ackermans, M.T.; Fliers, E.; la Fleur, S.E.; Serlie, M.J. Hypercaloric diets with increased meal frequency, but not meal size, increase intrahepatic triglycerides: A randomized controlled trial. Hepatology 2014, 60, 545-553. [CrossRef]

34. Madan, S.A.; John, F.; Pyrsopoulos, N.; Pitchumoni, C.S. Nonalcoholic fatty liver disease and carotid artery atherosclerosis in children and adults: A meta-analysis. Eur. J. Gastroenterol. Hepatol. 2015, 27, 1237-1248. [CrossRef] [PubMed]

35. Malik, V.S.; Popkin, B.M.; Bray, G.A.; Despres, J.P.; Hu, F.B. Sugar-sweetened beverages, obesity, type 2 diabetes mellitus, and cardiovascular disease risk. Circulation 2010, 121, 1356-1364. [CrossRef]

36. Fung, T.T.; Malik, V.; Rexrode, K.M.; Manson, J.E.; Willett, W.C.; Hu, F.B. Sweetened beverage consumption and risk of coronary heart disease in women. Am. J. Clin. Nutr. 2009, 89, 1037-1042. [CrossRef]

37. Yang, Q.; Zhang, Z.; Gregg, E.W.; Flanders, W.D.; Merritt, R.; Hu, F.B. Added sugar intake and cardiovascular diseases mortality among US adults. JAMA Intern. Med. 2014, 174, 516-524. [CrossRef]

38. Bernstein, A.M.; de Koning, L.; Flint, A.J.; Rexrode, K.M.; Willett, W.C. Soda consumption and the risk of stroke in men and women. Am. J. Clin. Nutr. 2012, 95, 1190-1199. [CrossRef]

39. Eshak, E.S.; Iso, H.; Kokubo, Y.; Saito, I.; Yamagishi, K.; Inoue, M.; Tsugane, S. Soft drink intake in relation to incident ischemic heart disease, stroke, and stroke subtypes in Japanese men and women: The Japan Public Health Centre-based study cohort I. Am. J. Clin. Nutr. 2012, 96, 1390-1397. [CrossRef] 
40. Piepoli, M.F.; Hoes, A.W.; Agewall, S.; Albus, C.; Brotons, C.; Catapano, A.L.; Cooney, M.T.; Corrà, U.; Cosyns, B.; Deaton, C.; et al. 2016 European Guidelines on cardiovascular disease prevention in clinical practice. Rev. Esp. Cardiol. (Engl. Ed.) 2016, 69, 939. [CrossRef]

41. Rebollo, A.; Roglans, N.; Alegret, M.; Laguna, J.C. Way back for fructose and liver metabolism: Bench side to molecular insights. World J. Gastroenterol. 2012, 18, 6552-6559. [CrossRef] [PubMed]

42. Jin, R.; Welsh, J.A.; Le, N.A.; Holzberg, J.; Sharma, P.; Martin, D.R.; Vos, M.B. Dietary fructose reduction improves markers of cardiovascular disease risk in Hispanic-American adolescents with NAFLD. Nutrients 2014, 6, 3187-3201. [CrossRef] [PubMed]

43. Anderson, J.W.; Hanna, T.J.; Peng, X.; Kryscio, R.J. Whole grain foods and heart disease risk. J. Am. Coll. Nutr. 2000, 19, 291S-299S. [CrossRef] [PubMed]

44. Katcher, H.I.; Legro, R.S.; Kunselman, A.R.; Gillies, P.J.; Demers, L.M.; Bagshaw, D.M.; Kris-Etherton, P.M. The effects of a whole grain-enriched hypocaloric diet on cardiovascular disease risk factors in men and women with metabolic syndrome. Am. J. Clin. Nutr. 2008, 87, 79-90. [CrossRef] [PubMed]

45. Mellen, P.B.; Walsh, T.F.; Herrington, D.M. Whole grain intake and cardiovascular disease: A meta-analysis. Nutr. Metab. Cardiovasc. Dis. 2008, 18, 283-290. [CrossRef]

46. White, B. Dietary fatty acids. Am. Fam. Physician 2009, 80, 345-350.

47. Choque, B.; Catheline, D.; Rioux, V.; Legrand, P. Linoleic acid: Between doubts and certainties. Biochimie 2014, 96, 14-21. [CrossRef]

48. Cordain, L.; Eaton, S.B.; Sebastian, A.; Mann, N.; Lindeberg, S.; Watkins, B.A.; O'Keefe, J.H.; Brand-Miller, J. Origins and evolution of the Western diet: Health implications for the 21st century. Am. J. Clin. Nutr. 2005, 81, 341-354. [CrossRef]

49. Donnelly, K.L.; Smith, C.I.; Schwarzenberg, S.J.; Jessurun, J.; Boldt, M.D.; Parks, E.J. Sources of fatty acids stored in liver and secreted via lipoproteins in patients with nonalcoholic fatty liver disease. J. Clin. Investig. 2005, 115, 1343-1351. [CrossRef]

50. Musso, G.; Gambino, R.; De Michieli, F.; Cassader, M.; Rizzetto, M.; Durazzo, M.; Fagà, E.; Silli, B.; Pagano, G. Dietary habits and their relations to insulin resistance and postprandial lipemia in nonalcoholic steatohepatitis. Hepatology 2003, 37, 909-916. [CrossRef]

51. Toshimitsu, K.; Matsuura, B.; Ohkubo, I.; Niiya, T.; Furukawa, S.; Hiasa, Y.; Kawamura, M.; Ebihara, K.; Onji, M. Dietary habits and nutrient intake in non-alcoholic steatohepatitis. Nutrition 2007, 23, 46-52. [CrossRef] [PubMed]

52. Araya, J.; Rodrigo, R.; Videla, L.A.; Thielemann, L.; Orellana, M.; Pettinelli, P.; Poniachik, J. Increase in long-chain polyunsaturated fatty acid $n-6 / n-3$ ratio in relation to hepatic steatosis in patients with non-alcoholic fatty liver disease. Clin. Sci. (Lond.) 2004, 106, 635-643. [CrossRef]

53. Elizondo, A.; Araya, J.; Rodrigo, R.; Poniachik, J.; Csendes, A.; Maluenda, F.; Díaz, J.C.; Signorini, C.; Sgherri, C.; Comporti, M.; et al. Polyunsaturated fatty acid pattern in liver and erythrocyte phospholipids from obese patients. Obesity (Silver Spring) 2007, 15, 24-31. [CrossRef] [PubMed]

54. Jump, D.B.; Lytle, K.A.; Depner, C.M.; Tripathy, S. Omega-3 polyunsaturated fatty acids as a treatment strategy for nonalcoholic fatty liver disease. Pharmacol. Ther. 2018, 181, 108-125. [CrossRef] [PubMed]

55. Levy, J.R.; Clore, J.N.; Stevens, W. Dietary n-3 polyunsaturated fatty acids decrease hepatic triglycerides in Fischer 344 rats. Hepatology 2004, 39, 608-616. [CrossRef]

56. Sekiya, M.; Yahagi, N.; Matsuzaka, T.; Najima, Y.; Nakakuki, M.; Nagai, R.; Ishibashi, S.; Osuga, J.I.; Yamada, N.; Shimano, H. Polyunsaturated fatty acids ameliorate hepatic steatosis in obese mice by SREBP-1 suppression. Hepatology 2003, 38, 1529-1539. [CrossRef]

57. Depner, C.M.; Traber, M.G.; Bobe, G.; Kensicki, E.; Bohren, K.M.; Milne, G.; Jump, D.B. A metabolomic analysis of omega-3 fatty acid-mediated attenuation of western diet-induced nonalcoholic steatohepatitis in LDLR-/- mice. PLoS ONE 2013, 8, e83756. [CrossRef]

58. Lytle, K.A.; Wong, C.P.; Jump, D.B. Docosahexaenoic acid blocks progression of western diet-induced nonalcoholic steatohepatitis in obese Ldlr-/- mice. PLOS ONE 2017, 12, e0173376. [CrossRef]

59. Rosqvist, F.; Iggman, D.; Kullberg, J.; Cedernaes, J.; Johansson, H.E.; Larsson, A.; Johansson, L.; Ahlström, H.; Arner, P.; Dahlman, I.; et al. Overfeeding polyunsaturated and saturated fat causes distinct effects on liver and visceral fat accumulation in humans. Diabetes 2014, 63, 2356-2368. [CrossRef]

60. Bjermo, H.; Iggman, D.; Kullberg, J.; Dahlman, I.; Johansson, L.; Persson, L.; Berglund, J.; Pulkki, K.; Basu, S.; Uusitupa, M.; et al. Effects of n-6 PUFAs compared with SFAs on liver fat, lipoproteins, and inflammation in abdominal obesity: A randomized controlled trial. Am. J. Clin. Nutr. 2012, 95, 1003-1012. [CrossRef] 
61. Errazuriz, I.; Dube, S.; Slama, M.; Visentin, R.; Nayar, S.; O'Connor, H.; Cobelli, C.; Das, S.K.; Basu, A.; Kremers, W.K.; et al. Randomized Controlled Trial of a MUFA or Fiber-Rich Diet on Hepatic Fat in Prediabetes. J. Clin. Endocrinol. Metab. 2017, 102, 1765-1774. [CrossRef]

62. Bozzetto, L.; Prinster, A.; Annuzzi, G.; Costagliola, L.; Mangione, A.; Vitelli, A.; Mazzarella, R.; Longobardo, M.; Mancini, M.; Vigorito, C.; et al. Liver fat is reduced by an isoenergetic MUFA diet in a controlled randomized study in type 2 diabetic patients. Diabetes Care 2012, 35, 1429-1435. [CrossRef] [PubMed]

63. Ryan, M.C.; Itsiopoulos, C.; Thodis, T.; Ward, G.; Trost, N.; Hofferberth, S.; O'Dea, K.; Desmond, P.V.; Johnson, N.A.; Wilson, A.M. The Mediterranean diet improves hepatic steatosis and insulin sensitivity in individuals with non-alcoholic fatty liver disease. J. Hepatol. 2013, 59, 138-143. [CrossRef] [PubMed]

64. European Association for the Study of the Liver; European Association for the Study of Diabetes; European Association for the Study of Obesity. EASL-EASD-EASO Clinical Practice Guidelines for the management of non-alcoholic fatty liver disease. Diabetologia 2016, 59, 1121-1140. [CrossRef] [PubMed]

65. Sui, Y.H.; Luo, W.J.; Xu, Q.Y.; Hua, J. Dietary saturated fatty acid and polyunsaturated fatty acid oppositely affect hepatic NOD-like receptor protein 3 inflammasome through regulating nuclear factor-kappa B activation. World J. Gastroenterol. 2016, 22, 2533-2544. [CrossRef]

66. Jasirwan, C.O.M.; Lesmana, C.R.A.; Hasan, I.; Sulaiman, A.S.; Gani, R.A. The role of gut microbiota in non-alcoholic fatty liver disease: Pathways of mechanisms. Biosci. Microbiota Food Health 2019, 38, 81-88. [CrossRef]

67. Meex, R.C.R.; Blaak, E.E. Mitochondrial Dysfunction is a Key Pathway that Links Saturated Fat Intake to the Development and Progression of NAFLD. Mol. Nutr. Food. Res. 2020, e1900942. [CrossRef]

68. Lottenberg, A.M.; Afonso Mda, S.; Lavrador, M.S.; Machado, R.M.; Nakandakare, E.R. The role of dietary fatty acids in the pathology of metabolic syndrome. J. Nutr. Biochem. 2012, 23, 1027-1040. [CrossRef]

69. Lytle, K.A.; Depner, C.M.; Wong, C.P.; Jump, D.B. Docosahexaenoic acid attenuates Western diet-induced hepatic fibrosis in Ldlr-/- mice by targeting the TGFbeta-Smad3 pathway. J. Lipid. Res. 2015, 56, 1936-1946. [CrossRef]

70. Collaborators, G.B.D.R.F.; Forouzanfar, M.H.; Alexander, L.; Anderson, H.R.; Bachman, V.F.; Biryukov, S.; Brauer, M.; Burnett, R.; Casey, D.; Coates, M.M.; et al. Global, regional, and national comparative risk assessment of 79 behavioural, environmental and occupational, and metabolic risks or clusters of risks in 188 countries, 1990-2013: A systematic analysis for the Global Burden of Disease Study 2013. Lancet 2015, 386, 2287-2323. [CrossRef]

71. Linseisen, J.; Welch, A.A.; Ocke, M.; Amiano, P.; Agnoli, C.; Ferrari, P.; Sonestedt, E.; Chajès, V.; Bueno-de-Mesquita, H.B.; Kaaks, R.; et al. Dietary fat intake in the European Prospective Investigation into Cancer and Nutrition: Results from the 24-h dietary recalls. Eur. J. Clin. Nutr. 2009, 63, S61-S80. [CrossRef] [PubMed]

72. Molendi-Coste, O.; Legry, V.; Leclercq, I.A. Why and How Meet n-3 PUFA Dietary Recommendations? Gastroenterol. Res. Pract. 2011, 2011, 364040. [CrossRef] [PubMed]

73. Simopoulos, A.P. The importance of the ratio of omega-6/omega-3 essential fatty acids. Biomed. Pharmacother. 2002, 56, 365-379. [CrossRef]

74. Das, U.N. Essential fatty acids and their metabolites could function as endogenous HMG-CoA reductase and ACE enzyme inhibitors, anti-arrhythmic, anti-hypertensive, anti-atherosclerotic, anti-inflammatory, cytoprotective, and cardioprotective molecules. Lipids Health Dis. 2008, 37. [CrossRef] [PubMed]

75. Berryman, C.E.; Preston, A.G.; Karmally, W.; Deckelbaum, R.J.; Kris-Etherton, P.M. Effects of almond consumption on the reduction of LDL-cholesterol: A discussion of potential mechanisms and future research directions. Nutr. Rev. 2011, 69, 171-185. [CrossRef]

76. Martin de Santa Olalla, L.; Sanchez Muniz, F.J.; Vaquero, M.P. N-3 fatty acids in glucose metabolism and insulin sensitivity. Nutr. Hosp. 2009, 24, 113-127.

77. Harris, W.S.; Mozaffarian, D.; Lefevre, M.; Toner, C.D.; Colombo, J.; Cunnane, S.C.; Holden, J.M.; Klurfeld, D.M.; Morris, M.C.; Whelan, J. Towards establishing dietary reference intakes for eicosapentaenoic and docosahexaenoic acids. J. Nutr. 2009, 139, 804S-819S. [CrossRef]

78. Campos, H.; Baylin, A.; Willett, W.C. Alpha-linolenic acid and risk of nonfatal acute myocardial infarction. Circulation 2008, 118, 339-345. [CrossRef]

79. Yashodhara, B.M.; Umakanth, S.; Pappachan, J.M.; Bhat, S.K.; Kamath, R.; Choo, B.H. Omega-3 fatty acids: A comprehensive review of their role in health and disease. Postgrad. Med. J. 2009, 85, 84-90. [CrossRef]

80. Eaton, S.B.; Konner, M.J.; Cordain, L. Diet-dependent acid load, Paleolithic [corrected] nutrition, and evolutionary health promotion. Am. J. Clin. Nutr. 2010, 91, 295-297. [CrossRef] 
81. Nagata, C.; Takatsuka, N.; Shimizu, H. Soy and fish oil intake and mortality in a Japanese community. Am. J. Epidemiol. 2002, 156, 824-831. [CrossRef] [PubMed]

82. De Lorgeril, M.; Salen, P.; Martin, J.L.; Monjaud, I.; Delaye, J.; Mamelle, N. Mediterranean diet, traditional risk factors, and the rate of cardiovascular complications after myocardial infarction: Final report of the Lyon Diet Heart Study. Circulation 1999, 99, 779-885. [CrossRef] [PubMed]

83. Masterton, G.S.; Plevris, J.N.; Hayes, P.C. Review article: Omega-3 fatty acids-A promising novel therapy for non-alcoholic fatty liver disease. Aliment. Pharmacol. Ther. 2010, 31, 679-692. [CrossRef] [PubMed]

84. Perrone, M.A.; Gualtieri, P.; Gratteri, S.; Ali, W.; Sergi, D.; Muscoli, S.; Cammarano, A.; Bernardini, S.; Renzo, L.D.; Romeo, F. Effects of postprandial hydroxytyrosol and derivates on oxidation of LDL, cardiometabolic state and gene expression: A nutrigenomic approach for cardiovascular prevention. J. Cardiovasc. Med. (Hagerstown) 2019, 20, 419-426. [CrossRef] [PubMed]

85. Gentilcore, D.; Chaikomin, R.; Jones, K.L.; Russo, A.; Feinle-Bisset, C.; Wishart, J.M.; Rayner, C.K.; Horowitz, M. Effects of fat on gastric emptying of and the glycemic, insulin, and incretin responses to a carbohydrate meal in type 2 diabetes. J. Clin. Endocrinol. Metab. 2006, 91, 2062-2067. [CrossRef] [PubMed]

86. Eckel, R.H.; Jakicic, J.M.; Ard, J.D.; de Jesus, J.M.; Houston Miller, N.; Hubbard, V.S.; Lee, I.M.; Lichtenstein, A.H.; Loria, C.M.; Millen, B.E.; et al. 2013 AHA/ACC guideline on lifestyle management to reduce cardiovascular risk: A report of the American College of Cardiology/American Heart Association Task Force on Practice Guidelines. J. Am. Coll. Cardiol. 2014, 63, 2960-2984. [CrossRef]

87. Chalvon-Demersay, T.; Even, P.C.; Tome, D.; Chaumontet, C.; Piedcoq, J.; Gaudichon, C.; Azzout-Marniche, D. Low-protein diet induces, whereas high-protein diet reduces hepatic FGF21 production in mice, but glucose and not amino acids up-regulate FGF21 in cultured hepatocytes. J. Nutr. Biochem. 2016, 36, 60-67. [CrossRef]

88. Pichon, L.; Huneau, J.F.; Fromentin, G.; Tome, D. A high-protein, high-fat, carbohydrate-free diet reduces energy intake, hepatic lipogenesis, and adiposity in rats. J. Nutr. 2006, 136, 1256-1260. [CrossRef]

89. Zelber-Sagi, S.; Nitzan-Kaluski, D.; Goldsmith, R.; Webb, M.; Blendis, L.; Halpern, Z.; Oren, R. Long term nutritional intake and the risk for non-alcoholic fatty liver disease (NAFLD): A population based study. J. Hepatol. 2007, 47, 711-717. [CrossRef]

90. Cruz-Jentoft, A.J.; Bahat, G.; Bauer, J.; Boirie, Y.; Bruyere, O.; Cederholm, T.; Cooper, C.; Landi, F.; Rolland, Y.; Sayer, A.A.; et al. Sarcopenia: Revised European consensus on definition and diagnosis. Age Ageing 2019, 48,601 . [CrossRef]

91. Lee, Y.H.; Jung, K.S.; Kim, S.U.; Yoon, H.J.; Yun, Y.J.; Lee, B.W.; Kang, E.S.; Han, K.H.; Lee, H.C.; Cha, B.S. Sarcopaenia is associated with NAFLD independently of obesity and insulin resistance: Nationwide surveys (KNHANES 2008-2011). J. Hepatol. 2015, 63, 486-493. [CrossRef] [PubMed]

92. Tamura, Y.; Omura, T.; Toyoshima, K.; Araki, A. Nutrition Management in Older Adults with Diabetes: A Review on the Importance of Shifting Prevention Strategies from Metabolic Syndrome to Frailty. Nutrients 2020, 12, 3367. [CrossRef] [PubMed]

93. Liu, X.; Hu, Z.; Xu, X.; Li, Z.; Chen, Y.; Dong, J. The associations of plant-based protein intake with all-cause and cardiovascular mortality in patients on peritoneal dialysis. Nutr. Metab. Cardiovasc. Dis. 2020, 30, 967-976. [CrossRef] [PubMed]

94. Zhubi-Bakija, F.; Bajraktari, G.; Bytyci, I.; Mikhailidis, D.P.; Henein, M.Y.; Latkovskis, G.; Rexhaj, Z.; Zhubi, E.; Banach, M.; International Lipid Expert Panel (ILEP). The impact of type of dietary protein, animal versus vegetable, in modifying cardiometabolic risk factors: A position paper from the International Lipid Expert Panel (ILEP). Clin. Nutr. 2020. [CrossRef] [PubMed]

95. Fang, X.; An, P.; Wang, H.; Wang, X.; Shen, X.; Li, X.; Min, J.; Liu, S.; Wang, F. Dietary intake of heme iron and risk of cardiovascular disease: A dose-response meta-analysis of prospective cohort studies. Nutr. Metab. Cardiovasc. Dis. 2015, 25, 24-35. [CrossRef] [PubMed]

96. Pisano, G.; Lombardi, R.; Fracanzani, A.L. Vascular Damage in Patients with Nonalcoholic Fatty Liver Disease: Possible Role of Iron and Ferritin. Int. J. Mol. Sci. 2016, 17, 675. [CrossRef] [PubMed]

97. Kim, Y.; Hwang, S.W.; Kim, S.; Lee, Y.S.; Kim, T.Y.; Lee, S.H.; Kim, S.J.; Yoo, H.J.; Kim, E.N.; Kweon, M.N. Dietary cellulose prevents gut inflammation by modulating lipid metabolism and gut microbiota. Gut Microbes 2020, 11, 944-961. [CrossRef]

98. Di Caro, V.; Cummings, J.L.; Alcamo, A.M.; Piganelli, J.D.; Clark, R.S.B.; Morowitz, M.J.; Aneja, R.K. Dietary Cellulose Supplementation Modulates the Immune Response in a Murine Endotoxemia Model. Shock 2019, 51, 526-534. [CrossRef] 
99. Chambers, E.S.; Byrne, C.S.; Morrison, D.J.; Murphy, K.G.; Preston, T.; Tedford, C.; Garcia-Perez, I.; Fountana, S.; Serrano-Contreras, J.I.; Holmes, E.; et al. Dietary supplementation with inulin-propionate ester or inulin improves insulin sensitivity in adults with overweight and obesity with distinct effects on the gut microbiota, plasma metabolome and systemic inflammatory responses: A randomised cross-over trial. Gut 2019, 68, 1430-1438. [CrossRef]

100. Jayachandran, M.; Chen, J.; Chung, S.S.M.; Xu, B. A critical review on the impacts of beta-glucans on gut microbiota and human health. J. Nutr. Biochem. 2018, 61, 101-110. [CrossRef]

101. Miedema, M.D.; Petrone, A.; Shikany, J.M.; Greenland, P.; Lewis, C.E.; Pletcher, M.J.; Gaziano, J.M.; Djousse, L. Association of Fruit and Vegetable Consumption During Early Adulthood With the Prevalence of Coronary Artery Calcium After 20 Years of Follow-Up: The Coronary Artery Risk Development in Young Adults (CARDIA) Study. Circulation 2015, 132, 1990-1998. [CrossRef] [PubMed]

102. Dauchet, L.; Amouyel, P.; Hercberg, S.; Dallongeville, J. Fruit and vegetable consumption and risk of coronary heart disease: A meta-analysis of cohort studies. J. Nutr. 2006, 136, 2588-2593. [CrossRef] [PubMed]

103. Barrera, F.; George, J. The role of diet and nutritional intervention for the management of patients with NAFLD. Clin. Liver Dis. 2014, 18, 91-112. [CrossRef] [PubMed]

104. Loffredo, L.; Perri, L.; Di Castelnuovo, A.; Iacoviello, L.; De Gaetano, G.; Violi, F. Supplementation with vitamin $\mathrm{E}$ alone is associated with reduced myocardial infarction: A meta-analysis. Nutr. Metab. Cardiovasc. Dis. 2015, 25, 354-363. [CrossRef] [PubMed]

105. Joris, P.J.; Mensink, R.P. Effects of supplementation with the fat-soluble vitamins E and D on fasting flow-mediated vasodilation in adults: A meta-analysis of randomized controlled trials. Nutrients 2015, 7, 1728-1743. [CrossRef] [PubMed]

106. Cicero, A.F.G.; Colletti, A.; Bellentani, S. Nutraceutical Approach to Non-Alcoholic Fatty Liver Disease (NAFLD): The Available Clinical Evidence. Nutrients 2018, 10, 1153. [CrossRef] [PubMed]

107. Harrison, S.A.; Torgerson, S.; Hayashi, P.; Ward, J.; Schenker, S. Vitamin E and vitamin C treatment improves fibrosis in patients with nonalcoholic steatohepatitis. Am. J. Ogastroenterol. 2003, 98, 2485-2490. [CrossRef]

108. Foster, T.; Budoff, M.J.; Saab, S.; Ahmadi, N.; Gordon, C.; Guerci, A.D. Atorvastatin and antioxidants for the treatment of nonalcoholic fatty liver disease: The St Francis Heart Study randomized clinical trial. Am. J. Ogastroenterol. 2011, 106, 71-77. [CrossRef]

109. Benetti, E.; Mastrocola, R.; Chiazza, F.; Nigro, D.; D'Antona, G.; Bordano, V.; Fantozzi, R.; Aragno, M.; Collino, M.; Minetto, M.A. Effects of vitamin D on insulin resistance and myosteatosis in diet-induced obese mice. PLoS ONE 2018, 13, e0189707. [CrossRef]

110. Keane, J.T.; Elangovan, H.; Stokes, R.A.; Gunton, J.E. Vitamin D and the Liver-Correlation or Cause? Nutrients 2018, 10, 496. [CrossRef]

111. Barchetta, I.; Del Ben, M.; Angelico, F.; Di Martino, M.; Fraioli, A.; La Torre, G.; Saulle, R.; Perri, L.; Morini, S.; Tiberti, C.; et al. No effects of oral vitamin D supplementation on non-alcoholic fatty liver disease in patients with type 2 diabetes: A randomized, double-blind, placebo-controlled trial. BMC Med. 2016, 14, 92. [CrossRef] [PubMed]

112. Fodor, D.; Albu, A.; Poanta, L.; Porojan, M. Vitamin K and vascular calcifications. Acta. Physiol. Hung. 2010, 97, 256-266. [CrossRef] [PubMed]

113. Shea, M.K.; Booth, S.L.; Miller, M.E.; Burke, G.L.; Chen, H.; Cushman, M.; Tracy, R.P.; Kritchevsky, S.B. Association between circulating vitamin $\mathrm{K} 1$ and coronary calcium progression in community-dwelling adults: The Multi-Ethnic Study of Atherosclerosis. Am. J. Clin. Nutr. 2013, 98, 197-208. [CrossRef] [PubMed]

114. Panahi, Y.; Kianpour, P.; Mohtashami, R.; Jafari, R.; Simental-Mendia, L.E.; Sahebkar, A. Curcumin Lowers Serum Lipids and Uric Acid in Subjects With Nonalcoholic Fatty Liver Disease: A Randomized Controlled Trial. J. Cardiovasc. Pharmacol. 2016, 68, 223-229. [CrossRef] [PubMed]

115. Selmanovic, S.; Beganlic, A.; Salihefendic, N.; Ljuca, F.; Softic, A.; Smajic, E. Therapeutic Effects of Curcumin on Ultrasonic Morphological Characteristics of Liver in Patients with Metabolic Syndrome. Acta Inform. Med. 2017, 25, 169-174. [CrossRef]

116. Xiao, J.; Sheng, X.; Zhang, X.; Guo, M.; Ji, X. Curcumin protects against myocardial infarction-induced cardiac fibrosis via SIRT1 activation in vivo and in vitro. Drug Des. Dev Ther. 2016, 10, 1267-1277. [CrossRef]

117. Wongcharoen, W.; Jai-Aue, S.; Phrommintikul, A.; Nawarawong, W.; Woragidpoonpol, S.; Tepsuwan, T.; Sukonthasarn, A.; Apaijai, N.; Chattipakorn, N. Effects of curcuminoids on frequency of acute myocardial infarction after coronary artery bypass grafting. Am. J. Cardiol. 2012, 110, 40-44. [CrossRef] 
118. Wu, X.; Huang, L.; Zhou, X.; Liu, J. Curcumin protects cardiomyopathy damage through inhibiting the production of reactive oxygen species in type 2 diabetic mice. Biochem. Biophys. Res. Commun. 2020, 530, 15-21. [CrossRef]

119. Banez, M.J.; Geluz, M.I.; Chandra, A.; Hamdan, T.; Biswas, O.S.; Bryan, N.S.; Von Schwarz, E.R. A systemic review on the antioxidant and anti-inflammatory effects of resveratrol, curcumin, and dietary nitric oxide supplementation on human cardiovascular health. Nutr. Res. 2020, 78, 11-26. [CrossRef]

120. Perez-Jimenez, J.; Fezeu, L.; Touvier, M.; Arnault, N.; Manach, C.; Hercberg, S.; Galan, P.; Scalbert, A. Dietary intake of 337 polyphenols in French adults. Am. J. Clin. Nutr. 2011, 93, 1220-1228. [CrossRef]

121. Annuzzi, G.; Bozzetto, L.; Costabile, G.; Giacco, R.; Mangione, A.; Anniballi, G.; Vitale, M.; Vetrani, C.; Cipriano, P.; Corte, G.D.; et al. Diets naturally rich in polyphenols improve fasting and postprandial dyslipidemia and reduce oxidative stress: A randomized controlled trial. Am. J. Clin. Nutr. 2014, 99, 463-471. [CrossRef] [PubMed]

122. Sakata, R.; Nakamura, T.; Torimura, T.; Ueno, T.; Sata, M. Green tea with high-density catechins improves liver function and fat infiltration in non-alcoholic fatty liver disease (NAFLD) patients: A double-blind placebo-controlled study. Int. J. Mol. Med. 2013, 32, 989-994. [CrossRef] [PubMed]

123. Poulsen, M.M.; Vestergaard, P.F.; Clasen, B.F.; Radko, Y.; Christensen, L.P.; Stodkilde-Jorgensen, H.; Møller, N.; Jessen, N.; Pedersen, S.B.; Jørgensen, J.O.L. High-dose resveratrol supplementation in obese men: An investigator-initiated, randomized, placebo-controlled clinical trial of substrate metabolism, insulin sensitivity, and body composition. Diabetes 2013, 62, 1186-1195. [CrossRef] [PubMed]

124. Della Pepa, G.; Vetrani, C.; Lombardi, G.; Bozzetto, L.; Annuzzi, G.; Rivellese, A.A. Isocaloric Dietary Changes and Non-Alcoholic Fatty Liver Disease in High Cardiometabolic Risk Individuals. Nutrients 2017, 9, 1065. [CrossRef]

125. Wijarnpreecha, K.; Thongprayoon, C.; Ungprasert, P. Coffee consumption and risk of nonalcoholic fatty liver disease: A systematic review and meta-analysis. Eur. J. Gastroenterol. Hepatol. 2017, 29, e8-e12. [CrossRef]

126. Schwimmer, J.B.; Celedon, M.A.; Lavine, J.E.; Salem, R.; Campbell, N.; Schork, N.J.; Shiehmorteza, M.; Yokoo, T.; Chavez, A.; Middleton, M.S.; et al. Heritability of nonalcoholic fatty liver disease. Gastroenterology 2009, 136, 1585-1592. [CrossRef]

127. Dongiovanni, P.; Donati, B.; Fares, R.; Lombardi, R.; Mancina, R.M.; Romeo, S.; Valenti, L. PNPLA3 I148M polymorphism and progressive liver disease. World J. Gastroenterol. 2013, 19, 6969-6978. [CrossRef]

128. Romeo, S.; Kozlitina, J.; Xing, C.; Pertsemlidis, A.; Cox, D.; Pennacchio, L.A.; Boerwinkle, E.; Cohen, J.C.; Hobbs, H.H. Genetic variation in PNPLA3 confers susceptibility to nonalcoholic fatty liver disease. Nat. Genet. 2008, 40, 1461-1465. [CrossRef]

129. Kozlitina, J.; Smagris, E.; Stender, S.; Nordestgaard, B.G.; Zhou, H.H.; Tybjaerg-Hansen, A.; Vogt, T.F.; Hobbs, H.H.; Cohen, J.C. Exome-wide association study identifies a TM6SF2 variant that confers susceptibility to nonalcoholic fatty liver disease. Nat. Genet. 2014, 46, 352-356. [CrossRef]

130. Mancina, R.M.; Dongiovanni, P.; Petta, S.; Pingitore, P.; Meroni, M.; Rametta, R.; Borén, J.; Montalcini, T.; Pujia, A.; Wiklund, O.; et al. The MBOAT7-TMC4 Variant rs641738 Increases Risk of Nonalcoholic Fatty Liver Disease in Individuals of European Descent. Gastroenterology 2016, 150, 1219-1230. [CrossRef]

131. Beer, N.L.; Tribble, N.D.; McCulloch, L.J.; Roos, C.; Johnson, P.R.; Orho-Melander, M.; Gloyn, A.L. The P446L variant in GCKR associated with fasting plasma glucose and triglyceride levels exerts its effect through increased glucokinase activity in liver. Hum. Mol. Genet. 2009, 18, 4081-4088. [CrossRef] [PubMed]

132. Chen, Y.Y.; Wang, B.N.; Yu, X.P. Correlation between the $677 \mathrm{C}>\mathrm{T}$ polymorphism in the methylene tetrahydrofolate reductase gene and serum homocysteine levels in coronary heart disease. Genet. Mol. Res. 2016, 15. [CrossRef] [PubMed]

133. Raina, J.K.; Sharma, M.; Panjaliya, R.K.; Bhagat, M.; Sharma, R.; Bakaya, A.; Kumar, P. Methylenetetrahydrofolate reductase $\mathrm{C} 677 \mathrm{~T}$ and methionine synthase $\mathrm{A} 2756 \mathrm{G}$ gene polymorphisms and associated risk of cardiovascular diseases: A study from Jammu region. Indian Heart J. 2016, 68, 421-430. [CrossRef]

134. Do, R.; Stitziel, N.O.; Won, H.H.; Jorgensen, A.B.; Duga, S.; Angelica Merlini, P.; Kiezun, A.; Farrall, M.; Goel, A.; Zuk, O.; et al. Exome sequencing identifies rare LDLR and APOA5 alleles conferring risk for myocardial infarction. Nature 2015, 518, 102-106. [CrossRef]

135. Knoblauch, H.; Bauerfeind, A.; Toliat, M.R.; Becker, C.; Luganskaja, T.; Gunther, U.P.; Rohde, K.; Schuster, H.; Junghans, C.; Luft, F.C.; et al. Haplotypes and SNPs in 13 lipid-relevant genes explain most of the genetic variance in high-density lipoprotein and low-density lipoprotein cholesterol. Hum. Mol. Genet. 2004, 13, 993-1004. [CrossRef] [PubMed] 
136. Zhang, Y.; Tang, H.Q.; Peng, W.J.; Zhang, B.B.; Liu, M. Meta-analysis for the Association of Apolipoprotein E epsilon2/epsilon3/epsilon4 Polymorphism with Coronary Heart Disease. Chin. Med. J. (Engl.) 2015, 128, 1391-1398. [CrossRef]

137. Hesketh, J. Personalised nutrition: How far has nutrigenomics progressed? Eur. J. Clin. Nutr. 2013, 67, 430-435. [CrossRef]

138. Stender, S.; Kozlitina, J.; Nordestgaard, B.G.; Tybjaerg-Hansen, A.; Hobbs, H.H.; Cohen, J.C. Adiposity amplifies the genetic risk of fatty liver disease conferred by multiple loci. Nat. Genet. 2017, 49, 842-847. [CrossRef]

139. Tian, C.; Stokowski, R.P.; Kershenobich, D.; Ballinger, D.G.; Hinds, D.A. Variant in PNPLA3 is associated with alcoholic liver disease. Nat. Genet. 2010, 42, 21-23. [CrossRef]

140. Davis, J.N.; Le, K.A.; Walker, R.W.; Vikman, S.; Spruijt-Metz, D.; Weigensberg, M.J.; Allayee, H.; Goran, M.I. Increased hepatic fat in overweight Hispanic youth influenced by interaction between genetic variation in PNPLA3 and high dietary carbohydrate and sugar consumption. Am. J. Clin. Nutr. 2010, 92, 1522-1527. [CrossRef]

141. Nobili, V.; Liccardo, D.; Bedogni, G.; Salvatori, G.; Gnani, D.; Bersani, I.; Alisi, A.; Valenti, L.; Raponi, M. Influence of dietary pattern, physical activity, and I148M PNPLA3 on steatosis severity in at-risk adolescents. Genes Nutr. 2014, 9, 392. [CrossRef] [PubMed]

142. Santoro, N.; Savoye, M.; Kim, G.; Marotto, K.; Shaw, M.M.; Pierpont, B.; Caprio, S. Hepatic fat accumulation is modulated by the interaction between the rs738409 variant in the PNPLA3 gene and the dietary omega6/omega3 PUFA intake. PLoS ONE 2012, 7, e37827. [CrossRef] [PubMed]

143. Scorletti, E.; West, A.L.; Bhatia, L.; Hoile, S.P.; McCormick, K.G.; Burdge, G.C.; Lillycrop, K.A.; Clough, G.F.; Calder, P.C.; Byrne, C.D. Treating liver fat and serum triglyceride levels in NAFLD, effects of PNPLA3 and TM6SF2 genotypes: Results from the WELCOME trial. J. Hepatol. 2015, 63, 1476-1483. [CrossRef] [PubMed]

144. Musso, G.; Cipolla, U.; Cassader, M.; Pinach, S.; Saba, F.; De Michieli, F.; Paschetta, E.; Bongiovanni, D.; Framarin, L.; Leone, N.; et al. TM6SF2 rs58542926 variant affects postprandial lipoprotein metabolism and glucose homeostasis in NAFLD. J. Lipid Res. 2017, 58, 1221-1229. [CrossRef]

145. O'Hare, E.A.; Yang, R.; Yerges-Armstrong, L.M.; Sreenivasan, U.; McFarland, R.; Leitch, C.C.; Wilson, M.H.; Narina, S.; Gorden, A.; Ryan, K.A.; et al. TM6SF2 rs58542926 impacts lipid processing in liver and small intestine. Hepatology 2017, 65, 1526-1542. [CrossRef]

146. Meroni, M.; Dongiovanni, P.; Longo, M.; Carli, F.; Baselli, G.; Rametta, R.; Pelusi, S.; Badiali, S.; Maggioni, M.; Gaggini, M.; et al. Mboat7 down-regulation by hyper-insulinemia induces fat accumulation in hepatocytes. EBioMedicine 2020, 52, 102658. [CrossRef]

147. Nettleton, J.A.; McKeown, N.M.; Kanoni, S.; Lemaitre, R.N.; Hivert, M.F.; Ngwa, J.; van Rooij, F.J.A.; Sonestedt, E.; Wojczynski, M.K.; Ye, A.; et al. Interactions of dietary whole-grain intake with fasting glucoseand insulin-related genetic loci in individuals of European descent: A meta-analysis of 14 cohort studies. Diabetes Care 2010, 33, 2684-2691. [CrossRef]

148. Corella, D.; Carrasco, P.; Sorli, J.V.; Estruch, R.; Rico-Sanz, J.; Martinez-Gonzalez, M.A.; Salas-Salvadó, J.; Covas, M.I.; Coltell, O.; Arós, F.; et al. Mediterranean diet reduces the adverse effect of the TCF7L2-rs7903146 polymorphism on cardiovascular risk factors and stroke incidence: A randomized controlled trial in a high-cardiovascular-risk population. Diabetes Care 2013, 36, 3803-3811. [CrossRef]

149. Tortosa-Caparros, E.; Navas-Carrillo, D.; Marin, F.; Orenes-Pinero, E. Anti-inflammatory effects of omega 3 and omega 6 polyunsaturated fatty acids in cardiovascular disease and metabolic syndrome. Crit. Rev. Food Sci. Nutr. 2017, 57, 3421-3429. [CrossRef]

150. Ordovas, J.M.; Corella, D.; Cupples, L.A.; Demissie, S.; Kelleher, A.; Coltell, O.; Wilson, P.W.F.; Schaefer, E.J.; Tucker, K. Polyunsaturated fatty acids modulate the effects of the APOA1 G-A polymorphism on HDL-cholesterol concentrations in a sex-specific manner: The Framingham Study. Am. J. Clin. Nutr. 2002, 75, 38-46. [CrossRef]

151. Egert, S.; Boesch-Saadatmandi, C.; Wolffram, S.; Rimbach, G.; Muller, M.J. Serum lipid and blood pressure responses to quercetin vary in overweight patients by apolipoprotein E genotype. J. Nutr. 2010, 140, 278-284. [CrossRef] [PubMed]

152. Yang, Y.; Ruiz-Narvaez, E.; Kraft, P.; Campos, H. Effect of apolipoprotein E genotype and saturated fat intake on plasma lipids and myocardial infarction in the Central Valley of Costa Rica. Hum. Biol. 2007, 79, 637-647. [CrossRef] [PubMed] 
153. Arigony, A.L.; de Oliveira, I.M.; Machado, M.; Bordin, D.L.; Bergter, L.; Pra, D.; Henriques, J.A.P. The influence of micronutrients in cell culture: A reflection on viability and genomic stability. Biomed. Res. Int. 2013, 2013, 597282. [CrossRef] [PubMed]

154. Santos, J.D.B.; Mendonca, A.A.S.; Sousa, R.C.; Silva, T.G.S.; Bigonha, S.M.; Santos, E.C.; Gonçalves, R.V.; Novaes, R.D. Food-drug interaction: Anabolic steroids aggravate hepatic lipotoxicity and nonalcoholic fatty liver disease induced by trans fatty acids. Food Chem. Toxicol. 2018, 116, 360-368. [CrossRef]

155. Nakajima, T.; Moriguchi, M.; Katagishi, T.; Sekoguchi, S.; Nishikawa, T.; Takashima, H.; Kimura, H.; Minami, M.; Itoh, Y.; Kagawa, K.; et al. Premature telomere shortening and impaired regenerative response in hepatocytes of individuals with NAFLD. Liver Int. 2006, 26, 23-31. [CrossRef]

156. Garcia-Calzon, S.; Martinez-Gonzalez, M.A.; Razquin, C.; Corella, D.; Salas-Salvado, J.; Martinez, J.A.; Zalba, J.; Marti, A. Pro12Ala polymorphism of the PPARgamma2 gene interacts with a mediterranean diet to prevent telomere shortening in the PREDIMED-NAVARRA randomized trial. Circ. Cardiovasc. Genet. 2015, 8, 91-99. [CrossRef]

157. Ferguson, L.R.; De Caterina, R.; Gorman, U.; Allayee, H.; Kohlmeier, M.; Prasad, C.; Choi, M.S.; Curi, R.; De Luis, D.A.; Gil, A.; et al. Guide and Position of the International Society of Nutrigenetics/Nutrigenomics on Personalised Nutrition: Part 1-Fields of Precision Nutrition. J. Nutrigenet. Nutr. 2016, 9, 12-27. [CrossRef]

158. Navarro-Ibarra, M.J.; Hernandez, J.; Caire-Juvera, G. Diet, physical activity and telomere length in adults. Nutr. Hosp. 2019, 36, 1403-1417. [CrossRef]

159. Muller, M.; Kersten, S. Nutrigenomics: Goals and strategies. Nat. Rev. Genet. 2003, 4, 315-322. [CrossRef]

160. Alsaleh, A.; O’Dell, S.D.; Frost, G.S.; Griffin, B.A.; Lovegrove, J.A.; Jebb, S.A.; Sanders, T.A.B.; RISCK Study investigators. Interaction of PPARG Pro12Ala with dietary fat influences plasma lipids in subjects at cardiometabolic risk. J. Lipid Res. 2011, 52, 2298-2303. [CrossRef]

161. Volcik, K.A.; Nettleton, J.A.; Ballantyne, C.M.; Boerwinkle, E. Peroxisome proliferator-activated receptor [alpha] genetic variation interacts with n-6 and long-chain n-3 fatty acid intake to affect total cholesterol and LDL-cholesterol concentrations in the Atherosclerosis Risk in Communities Study. Am. J. Clin. Nutr. 2008, 87, 1926-1931. [CrossRef] [PubMed]

162. Razquin, C.; Alfredo Martinez, J.; Martinez-Gonzalez, M.A.; Corella, D.; Santos, J.M.; Marti, A. The Mediterranean diet protects against waist circumference enlargement in 12Ala carriers for the PPARgamma gene: 2 years' follow-up of 774 subjects at high cardiovascular risk. Br. J. Nutr. 2009, 102, 672-679. [CrossRef] [PubMed]

163. Meroni, M.; Longo, M.; Erconi, V.; Valenti, L.; Gatti, S.; Fracanzani, A.L.; Dongiovanni, P. mir-101-3p Downregulation Promotes Fibrogenesis by Facilitating Hepatic Stellate Cell Transdifferentiation During Insulin Resistance. Nutrients 2019, 11, 2597. [CrossRef] [PubMed]

164. Pirola, C.J.; Gianotti, T.F.; Burgueno, A.L.; Rey-Funes, M.; Loidl, C.F.; Mallardi, P.; Martino, J.S.; Castaño, G.O.; Sookoian, S. Epigenetic modification of liver mitochondrial DNA is associated with histological severity of nonalcoholic fatty liver disease. Gut 2013, 62, 1356-1363. [CrossRef] [PubMed]

165. Podrini, C.; Borghesan, M.; Greco, A.; Pazienza, V.; Mazzoccoli, G.; Vinciguerra, M. Redox homeostasis and epigenetics in non-alcoholic fatty liver disease (NAFLD). Curr. Pharm. Des. 2013, 19, 2737-2746. [CrossRef]

166. Wang, L.J.; Zhang, H.W.; Zhou, J.Y.; Liu, Y.; Yang, Y.; Chen, X.L.; Zhu, C.H.; Zheng, R.D.; Ling, W.H.; Zhu, H.L. Betaine attenuates hepatic steatosis by reducing methylation of the MTTP promoter and elevating genomic methylation in mice fed a high-fat diet. J. Nutr. Biochem. 2014, 25, 329-336. [CrossRef]

167. Pooya, S.; Blaise, S.; Moreno Garcia, M.; Giudicelli, J.; Alberto, J.M.; Gueant-Rodriguez, R.M.; Jeannesson, E.; Gueguen, N.; Bressenot, A.; Nicolas, B.; et al. Methyl donor deficiency impairs fatty acid oxidation through PGC-1alpha hypomethylation and decreased ER-alpha, ERR-alpha, and HNF-4alpha in the rat liver. J. Hepatol. 2012, 57, 344-351. [CrossRef]

168. Cordero, P.; Milagro, F.I.; Campion, J.; Martinez, J.A. Maternal methyl donors supplementation during lactation prevents the hyperhomocysteinemia induced by a high-fat-sucrose intake by dams. Int. J. Mol. Sci. 2013, 14, 24422-24437. [CrossRef]

169. Whayne, T.F. Epigenetics in the development, modification, and prevention of cardiovascular disease. Mol. Biol. Rep. 2015, 42, 765-776. [CrossRef]

170. Chang, H.C.; Guarente, L. SIRT1 and other sirtuins in metabolism. Trends Endocrinol. Metab. 2014, 25, 138-145. [CrossRef] 
171. Lee, J.H.; Friso, S.; Choi, S.W. Epigenetic mechanisms underlying the link between non-alcoholic fatty liver diseases and nutrition. Nutrients 2014, 6, 3303-3325. [CrossRef] [PubMed]

172. Tan, J.; McKenzie, C.; Potamitis, M.; Thorburn, A.N.; Mackay, C.R.; Macia, L. The role of short-chain fatty acids in health and disease. Adv. Immunol. 2014, 121, 91-119. [CrossRef] [PubMed]

173. Long, J.K.; Dai, W.; Zheng, Y.W.; Zhao, S.P. miR-122 promotes hepatic lipogenesis via inhibiting the LKB1/AMPK pathway by targeting Sirt1 in non-alcoholic fatty liver disease. Mol. Med. 2019, 25, 26. [CrossRef] [PubMed]

174. Zhang, L.; Hou, D.; Chen, X.; Li, D.; Zhu, L.; Zhang, Y.; Li, J.; Bian, Z.; Liang, X.Y.; Cai, X.; et al. Exogenous plant MIR168a specifically targets mammalian LDLRAP1: Evidence of cross-kingdom regulation by microRNA. Cell Res. 2012, 22, 107-126. [CrossRef] [PubMed]

175. Palmer, J.D.; Soule, B.P.; Simone, B.A.; Zaorsky, N.G.; Jin, L.; Simone, N.L. MicroRNA expression altered by diet: Can food be medicinal? Ageing Res. Rev. 2014, 17, 16-24. [CrossRef] [PubMed]

176. Wankhade, U.D.; Zhong, Y.; Kang, P.; Alfaro, M.; Chintapalli, S.V.; Thakali, K.M.; Shankar, K. Enhanced offspring predisposition to steatohepatitis with maternal high-fat diet is associated with epigenetic and microbiome alterations. PLoS ONE 2017, 12, e0175675. [CrossRef] [PubMed]

Publisher's Note: MDPI stays neutral with regard to jurisdictional claims in published maps and institutional affiliations.

(C) 2020 by the authors. Licensee MDPI, Basel, Switzerland. This article is an open access article distributed under the terms and conditions of the Creative Commons Attribution (CC BY) license (http://creativecommons.org/licenses/by/4.0/). 